
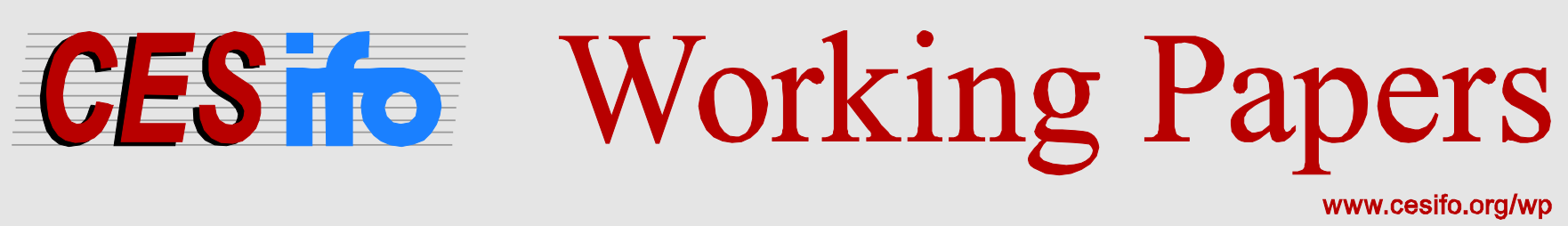

\title{
The Relevance or Otherwise of the Central Bank’s Balance Sheet
}

\author{
David K. Miles \\ Jochen Schanz
}

CESIFO WORKING PAPER NO. 4615

CATEGORY 7: MONETARY POLICY AND INTERNATIONAL FINANCE

JANUARY 2014

An electronic version of the paper may be downloaded

- from the SSRN website:

- from the RePEc website:

- from the CESifo website:

wWW.SSRN.com

Www.RePEc.org

www.CESifo-group.org/wp

\section{CESifo}




\title{
The Relevance or Otherwise of the Central Bank’s Balance Sheet
}

\begin{abstract}
This paper explores the impacts on an economy of a central bank changing the size and composition of its balance sheet. One of the ways in which such asset purchases could influence prices and demand is via portfolio balance effects. We develop and calibrate a simple OLG model in which risk-averse households hold money and bonds to insure against risk. Central bank asset purchases have the potential to affect households' choices by changing the composition and return of their asset portfolios. We find that the effect is weak, and that its size depends on how fiscal policy is conducted. That is not to say that the big expansion of central bank balance sheets in recent years has been ineffective. Our finding is rather that the portfolio balance channel evaluated in an environment of normally functioning (though nonetheless incomplete) asset markets is weak. That is not inconsistent with the evidence that large-scale asset purchases by central banks since 2008 have had significant effects, because those purchases were made when financial markets were, to varying extents, dysfunctional. Nonetheless our results are relevant to those purchases because they may be unwound in an environment where financial markets are no longer dysfunctional.
\end{abstract}

JEL-Code: E510, E520.

Keywords: unconventional monetary policy, quantitative easing.

David K. Miles

The Monetary Policy Committee

Bank of England

UK / London

david.miles@bankofengland.co.uk
Jochen Schanz

Bank of England

UK / London

jochen.schanz@bankofengland.co.uk

(This version, January 3, 2014)

The views in this paper are those of the authors, not of the Bank of England or its Monetary Policy Committee. The authors would like to thank Stephanie Schmitt-Grohe and Hugh Pill for helpfulcomments and suggestions. 


\section{Introduction}

This paper explores the impacts on an economy of a central bank changing the size and composition of its balance sheet. Whether the central bank purchasing longer term bonds can affect the real economy is a key policy issue. Major central banks - the Fed, the Bank of England and the Bank of Japan - have massively expanded their balance sheets in recent years in an attempt to stimulate demand in the wake of the financial crisis of 2007-08. (The ECB also substantially increased its balance sheet - though less through outright purchases of securities). There is a good deal of empirical evidence that such purchases have had a positive impact - both on asset prices and on demand. (For a recent review of the empirical evidence on the impact of asset purchases - or quantitative easing (QE) - see the special issue of the Economic Journal, November 2012. For an overview of the empirical and theoretical issues see Joyce, Miles, Scott and Vayanos (2012) and Zampolli (2012)).

One of the ways in which such asset purchases could influence prices and demand is via portfolio balance effects - that is through the impact that changes in the relative amount of money and bonds in private sector portfolios has upon asset values and demand. It is the significance of this portfolio channel that we assess in this paper. As Durre and Pill (2012) note this is not the only way in which expansion of the central balance sheet can affect the economy. Some central bank policies involve the substitution of flows of funds through the central bank balance sheet for flows between private financial firms. In times of stress this can keep credit flowing. But much recent empirical work (e.g. Gagnon et al (2010) and Joyce et al (2010)) focuses on the portfolio balance channel and finds it is significant.

But the empirical evidence is not conclusive and its interpretation is clouded by the lack of a clear theoretical framework which allows one to understand how such central bank purchases might work. Indeed most of the theoretical literature has focused on why they might not work. Wallace (1981), Chamley and Polemarchakis (1984), Sargent and Smith (1987) and Woodford and Eggertson (2003), all present conditions under which asset purchases are completely ineffective. Wallace (1981) showed that the path of the government's stock of liabilities - that is the composition of its portfolio for a given fiscal policy - are irrelevant in a model with complete markets. In this case open market operations conducted by a central bank that purchases government bonds of any maturity in exchange for other liabilities with different maturities have no impact on real outcomes. Chamley and Polemarchakis (1984) showed that the neutrality result could also hold in a world with incomplete markets but only so long as the central bank purchased real assets. Sargent and Smith showed that a neutrality, or ineffectiveness, result for government financial policies (which include the kind of central bank purchases of assets we consider in this paper) could hold in a world in which government issued fiat currency is dominated in rate of return. But as in Chamley and Polemarchakis, the result holds for open market operations where physical capital is exchanged for currency (and where there are simultaneously alterations in lump sum taxes and transfers). In the Woodford and Eggertson model an infinitely lived, representative household maximizes utility in a world with complete markets and faces no limit on borrowing against future income. It is clear that with these assumptions central bank purchases - which are essentially swaps of assets with the representative agent can do nothing because that single representative agent owns the balance sheet of the central 
bank and such swaps do not change its opportunity set. But such an idealized economy is not likely to be a reliable guide to the impact of central bank purchases even in normal times, let alone in the environment of recent years and in the aftermath of a near - total collapse of financial markets and where the supply of credit was seriously disrupted.

Summarizing this literature we have the following results: with complete markets any asset purchases by a central bank in exchange for liabilities it issues and which are part of public sector overall liabilities will not affect real outcomes. With incomplete market, open market operations in real assets (capital or indexed bonds) may have no real affects in a general equilibrium model with market clearing. That neutrality result does not depend upon complete markets or an operative bequest motive.

But what we do not have is a result that says that open market operations in which the central banks buys nominal assets in exchange for its issuing its liabilities is ineffective in affecting real outcomes in a world of incomplete markets. But that is the relevant case when considering QE because as implemented by central banks in recent years it has been the purchase of nominal assets (largely nominal government debt) for central bank liabilities (money, largely in the form of reserves). This paper explores whether such asset purchases can affect real outcomes when markets are incomplete. The question we address is whether quantitative easing provides a useful policy tool in an incomplete markets setting where there is a zero lower bound constraint on the policy rate set by the central bank.

We do so using an OLG model - a set up that allows for heterogeneity amongst agents (some are old and some young) and limits to borrowing (the young and the old cannot borrow from each other). In the simplest OLG set up where there is no uncertainty the inefficiency in free market outcomes is because trade between generations as a means to smooth consumption over the life cycle of an agent is not feasible - the young will not trade goods with the old in exchange for promises which the old will not be around to honour. But in this world the introduction of fiat money (or debt) by a government can remove the inefficiency. Indeed a very simple monetary policy, or debt management policy, will allow equilibria in which welfare enhancing trade between the young and old is possible (See Weill (2008) for a very clear exposition of the arguments first developed by Samuelson (1958)). As is well known, with no uncertainty optimal policy is very simple; it can be implemented with a government run PAYGO transfer system; with issuance of public debt or with the supply of fiat money 1 it would not seem to require the kind of asset purchases undertaken under QE and which we consider in this paper. Things are more interesting in the more realistic case where there are sources of uncertainty which cannot be traded in financial markets. We use such a model, where agents cannot enter into efficient risk sharing trades with those of other generations, to analyze what role conventional monetary policy (i.e. interest rate policy) and fiscal policy can have in overcoming market incompleteness and ask whether unconventional monetary policy - asset purchases by the central bank - can be useful in such a world and where the zero lower bound on the policy rate may be binding.

\footnotetext{
${ }^{1}$ Weill, with a simple 2 period life, OLG model with no uncertainty, concisely makes the point about how fiscal policy or the use of money or the use of a PAYG social security system can each be used to remove the inefficiency thus: "Like a pay-as-you-go social security system and like public debt, Samuelsonian money "works" because it is part of a social contract: perpetual intergenerational redistribution from young to old in the case of social security, a long-lived government that does not default on its obligations in the case of public debt, or "a grand consensus on the use of . . greenbacks as a money of exchange."
} 
Our aim is to understand whether, under plausible assumptions about monetary and fiscal policy, central bank purchases of longer-term bonds - against reserves (as during quantitative easing) or against short-term bonds (as during the Federal Reserve's "Operation Twist") - can have a significant effect on real activity. In an OLG model with no bequest motive households cannot undo the variation in their portfolios that emerges as a result of central bank asset purchases. We also assume that there is no complete set of state-contingent securities. Households then have to invest in short- and long term bonds to partially insure against risk. These bonds earn different returns in equilibrium. This is because households are risk averse, and short term and long term financial assets allow them to respond to risks in different ways. In this case central bank asset purchases can - depending on how wide the range of fiscal instruments is - affect a household's wealth, and therefore its real decisions. We calibrate the model to see whether this effect is significant and whether QE can be part of optimal policy.

We find that the ineffectiveness result of Wallace and subsequent authors is, in many ways, surprisingly robust. Even when we restrict the range of fiscal tools to mean that asset purchases by the central bank are not neutral they are rarely very effective: the impact of central bank asset purchases on real variables is either exactly zero or very small.

We have three main results. First, we show that if the government can set lump sum taxes at different (non-zero) rates on different generations alive at the same time they can achieve optimal risk sharing with simple tax and monetary policy rules - there is no need for unconventional monetary policy and QE is not needed. Second, we show that the impact of asset purchases is exactly zero under a more restricted tax rule, in which the government balances its budget by adjusting taxes on the generation whose portfolio changed as a consequence of central bank asset purchases (the old). In this case, fiscal policy exactly undoes any effect asset purchases would otherwise have had on household's portfolio. Third, when taxes are levied only on the young asset purchases (QE) do have effects but these are very small. Some of these results echo the irrelevance results of Wallace (1981) and others. But they are derived in a model with finite lives, incomplete markets, a zero lower bound constraint on the policy rate and where asset purchases are of nominal assets. Our results illustrate the importance of considering the interactions of monetary and fiscal policy when studying the impact of monetary policy (a point recently stressed by Sims (2013)).

Our overall finding is that the portfolio balance effect of central bank asset purchases is weak in a wide range of environments. That is not to say that the big expansion of central bank balance sheets in recent years has been ineffective. Our finding is rather that the portfolio balance channel evaluated in an environment of normally functioning (though nonetheless incomplete) asset markets is weak. In effect we find that with incomplete markets the use of money (which can pay interest at rates set by the central bank) and some fiscal instruments (a tax rate and debt management) leaves little role for QE to play. But that is in a world where the markets for money and bonds do work efficiently. That still leaves the potential for central bank balance sheets to offer a venue that substitutes for private intermediation when markets seize up. As one referee of this paper put it, the central bank intermediation role of balance sheet policies may be qualitatively more important than the portfolio balance channel of $\mathrm{QE}$ transmission.

So our results are not inconsistent with the evidence that large-scale asset purchases by 
central banks since 2008 have had significant effects, because those purchases were made when financial markets were - to varying extents - dysfunctional. Nonetheless our results are relevant to those purchases because they may be unwound in an environment where financial markets are no longer dysfunctional.

In the first part of this paper we describe the model. Section 2 describes the model in non-technical terms; Section 3 presents the formal structure. Section 4 contains the results. We conclude in Section 5 ,

\section{Model Overview}

Following Wallace (1981), Sargent and Smith (1987) and others, we model the impact of central bank purchases of government bonds within the framework of an overlapping generations model. We investigate how central bank purchases of bonds affect: households' willingness to bear interest rate risk; the equilibrium return on bonds; and households' incentives to produce and consume.

There are two assets in the economy: money, and government bonds. Households live for two periods. When bonds are issued they also have a maturity of two periods. Each generation is born without an endowment but the ability to transform their own labor into a perishable consumption good. Production uses labor only; there is no capital accumulation. The production technology has stochastic productivity.

Each young household decides how much labor to supply to produce the consumption good, and how much of this to consume. They sell the remainder to old households, in exchange for money, and decide how many government bonds to buy. Because the consumption good perishes unless consumed, young households can only transfer wealth to when they are old by holding money or government bonds. Neither young nor old households can borrow.

Money is remunerated at the policy rate set by the central bank. Money could be thought of as Treasury-bills, or bills issued by the central bank. But we could just as well think that there are $100 \%$ reserve backed commercial banks that are intermediaries between households, who hold deposits, and the central bank, which pays interest on reserves. Either way, we can think of money in this model as deposits (reserves) of the central bank that are its liability and which pay a rate of interest equal to the central bank's policy rate. All money is interest bearing as long as the central bank sets a non-zero interest rate. We make this assumption because in developed economies non-interest bearing notes and coins are very much smaller than interest bearing accounts which can be easily used to finance transactions.

The Treasury issues bonds at a discount; bonds do not pay coupons. The amount issued is constant in each period. Bonds have a maturity of two periods at issuance. This fiscal rule is a very simple one which keeps the face value of debt constant (the market value of government debt depends on real shocks to productivity). Taxes, which are lump sum, are varied to satisfy the fiscal rule. We abstract from credit risk of government bonds. There is no liquidity risk in the model.

Households pay state-dependent nominal lump sum taxes to the Treasury. The government is able to levy different taxes on the young and old. Old households have simple decisions to 
make: they have no bequest motive so simply liquidate all their assets to finance purchasing the consumption good which they buy from young households. We assume old households do not supply labor.

What distinguishes money and bonds in our model? Money in this model is the only asset that can be used to buy goods. Bonds must be sold for money before they can be used for consumption. The central bank takes deposits, which we could think of as reserves that a commercial banking sector holds against deposits held by households. Reserves ("money") pay a 1 period interest rate set by the central bank. The central bank will use a policy rule to set the rate, which will be some function of the exogenous random variable in the model (productivity) and also a random shock. The two financial assets - money and bonds - differ because money has a known nominal value 1 period ahead (one plus the interest rate set by the central bank today) while newly issued bonds have a value one period ahead which depends on the interest rate that the central bank will set in the next period - which is not known today. Bonds with one period left to maturity are perfect substitutes for money because both assets have a know nominal value one period ahead. This means that the price of a one period bond is tied to the interest rate set by the central bank. The financial assets in the model are dramatically simple - in fact as simple as is possible while allowing longer dated government bonds to be imperfect substitutes for shorter dated financial assets. Because the maturity of bonds is only double the maturity of money in our model, one might also interpret what we call central-bank purchases of long bonds against money as similar to the Federal Reserve's Operation Twist, in which the FOMC financed purchases of long bonds by selling short bonds.

The central bank balance sheet is straightforward: it holds 1 and 2 period bonds as assets which it acquires in exchange for issuing money (its liability). Any profits (or losses) made by the central bank from its portfolio of assets and liabilities is passed to the Treasury and taxes are raised or lowered accordingly so as to insure that the Treasury can continue to issue an unchanged quantity of new bonds to replace those that mature.

In each period:

1. The stochastic productivity of young households becomes know. Young households decide how much labor to supply to produce the consumption good.

2. The Treasury issues new 2-period bonds to replace those that mature and collects taxes from households to balance the budget. The central bank decides how many of these newly issued bonds to buy, and what (non-negative) interest rate to set for the remuneration of money.

3. Old households receive interest on their money holdings and sell their bonds (which now have a remaining maturity of one period) to the central bank in exchange for money. The central bank has to accept all 1-period bonds sold by old households at the price implied by its choice for the policy rate. One can think of these transactions as open market operations conducted by the central bank to implement a particular decision over the policy rate.

4. Old households use their money to purchase some of the young households' newly-produced consumption good. 


\section{Model: Detailed Specification}

\subsection{Households}

Our notation is as follows. We index individual households by $j$. Labor supply of a young household born in period $t$ is $h_{j, t}$. Using this labor input, the household produces $y_{j, t}=$ $\omega_{t} h_{j, t}^{\alpha}$ real units of the consumption good. $\omega_{t}$ is an aggregate productivity shock, distributed independently across periods according to a normal distribution with mean $\mu_{\omega}$ and standard deviation $\sigma_{\omega}$. The young household's real consumption is $c_{j, t}^{Y}$. Its nominal money holdings are $m_{j, t}^{Y}$, and its holdings of bonds issued in $t$ and maturing in $t+2$ are denoted by $g_{j, t, t+2}^{Y}$. The market-clearing price of these bonds is $P_{t, t+2}^{g}$, and that of bonds with a remaining maturity of one period is $P_{t, t+1}^{g}$. The price of the consumption good is $P_{t}^{c}$. The lump-sum tax is denoted $\tau_{t}^{Y}$ if levied on the young, and $\tau_{t}^{O}$ if levied on the old. We do not indicate the dependence of the endogenous variables on the state variables of our model but it should be taken as read.

Each household's period utility is of the CRRA variety:

$$
u(c, h)=\frac{\left(c^{1-\rho}(1-h)^{\rho}\right)^{1-\sigma_{c}}-1}{1-\sigma_{c}}
$$

and lifetime utility (recalling no-one can work when they are old) is:

$$
U\left(c_{j, t}^{Y}, c_{j, t+1}^{O}, h_{j, t}\right)=u\left(c_{j, t}^{Y}, h_{j, t}\right)+\beta E\left[u\left(c_{j, t+1}^{O}, 0\right) \mid s_{t}\right]
$$

where the expectation is taken over future states given the household's information in period $t$, summarized by the model's state variables $s_{t}$. Each household maximizes its lifetime utility over $\left\{h_{j, t}, m_{j, t}, g_{j, t, t+2}^{Y}\right\}$ subject to the budget constraints

$$
\begin{aligned}
P_{t}^{c}\left(y_{j, t}-c_{j, t}^{Y}\right) & =m_{j, t}^{Y}+P_{t, t+2}^{g} g_{j, t, t+2}^{Y}+\tau_{t}^{Y} \\
m_{j, t}^{Y}\left(1+i_{t}\right)+P_{t+1, t+2}^{g} g_{j, t, t+2}^{Y}-\tau_{t+1}^{O} & =P_{t+1}^{c} c_{j, t+1}^{O}
\end{aligned}
$$

and $m_{j, t}^{Y}, g_{j, t, t+2}^{Y} \geq 0$. The left-hand side of $(3)$ is the proceeds from selling the consumption good, and the right-hand side is the young households' use of the proceeds: it holds some of it in money, uses some to purchase newly issued bonds, and pays some lump-sum taxes. Note that the young do not buy 1 period bonds, which are perfect substitutes for money. We assume that the central bank stands ready to swap one period bonds for money - these are open market operations required to establish a particular 1 period interest rate.

The left-hand side of $(4)$ is the nominal wealth of the old after taxes, $w_{j, t+1}^{O}$ : this is the sum of remunerated money holdings and the receipts from selling bonds (now 1-period) to the central bank, minus tax payments. (Notice that one could equally write this problem as one of choosing any other three of the period- $t$ decision variables $\left\{c_{j, t}^{Y}, h_{j, t}, m_{j, t}, g_{j, t, t+2}^{Y}\right\}$; it is clearly optimal for the old households to spend their entire nominal wealth on the consumption good in the absence of a bequest motive.) 


\subsection{Monetary policy}

The central bank's policy instruments are the nominal interest rate at which it remunerates money ('Bank Rate'), and the amount of newly issued government bonds that it buys. We will refer to the central bank's purchases of newly issued government bonds as 'quantitative easing', or QE. We also make the inconsequential assumption that it buys all bonds with a remaining maturity of one period from old households. The central bank's assets therefore comprise all government bonds with a remaining maturity of one period, and those newly issued government bonds which it chooses to buy as part of its QE operation. Its liabilities consist of money which we can think of as issued directly to households or else as held as reserves by commercial banks who issue deposits to households of exactly equivalent value. We assume that the central bank has no equity; instead, it is indemnified for any losses that it may make by the Treasury, and transfers any profits to the Treasury.

We assume that the central bank follows a policy rule that only depends on the exogenous state variables: the productivity shock, $\omega_{t}$, and the random innovations to the level of Bank Rate and its purchases of newly issued bonds. We think of the second and third shocks as monetary policy shocks. The monetary policy shocks are independently normally distributed with zero mean and standard deviations $\sigma_{\varepsilon i}$ and $\sigma_{\varepsilon g}$, respectively. In addition, we assume that the policy rule for the interest rate is linear, subject to a zero lower bound for Bank Rate $\left(i_{t} \geq 0\right)$. Within these bounds, the policy rule takes the form

$$
i_{t}=a_{1}+a_{2}\left(\omega_{t}-\mu_{\omega}\right)+\varepsilon_{i, t}
$$

where $a_{1}, a_{2}$ are scalars. The central bank's purchases are limited by the Treasury's (constant) issuance of bonds and it cannot issue its own liabilities $\left(g_{t}^{C B} \in[0, \gamma]\right)$.

\subsection{Fiscal policy}

Fiscal policy only involves setting the size of the nominal lump-sum taxes to levy on households. There are no government expenditures other than transfers to the central bank on maturity of the bonds, and those required to indemnify the central bank for any losses it may make. Government revenues consist only of taxes levied on households and of profits that the central bank may make.

We assume that the government aims to balance its budget in each period by levying an appropriate amount of lump-sum taxes. The amount of bonds issued is assumed to be constant in each period. (We set this quantity at $\gamma=1$ so that at any time there are bonds with aggregate face value of 2 outstanding). The costs of servicing the outstanding zero-coupon debt are booked on an accrual basis. In each period, the tax is then equal to the nominal return that that period's old earned on their portfolio:

$$
\tau_{t+1}^{Y}+\tau_{t+1}^{O}=i_{t} M_{t}^{Y}+\left(P_{t+1, t+2}^{g}-P_{t, t+2}^{g}\right)\left(\gamma-g_{t}^{C B}\right)
$$

The government may be able to levy non-zero lump sum taxes at different rates on the young and old alive at the same time. But tax policy may be more constrained. We will consider two 
more constrained scenarios: either the young are taxed $\left(\tau_{t+1}^{O}=0\right)$, or the old $\left(\tau_{t+1}^{Y}=0\right)$. If the old are taxed, each generation in equilibrium pays as tax the exact amount they earned on their financial assets during their lifetime. This should be interpreted as a fiscal policy that does not attempt to redistribute wealth across generations. It may therefore not come as a surprise that we find that central bank asset purchases have no impact under this tax rule: any impact of asset purchases on the return on households' portfolio is neutralized by this type of fiscal policy. In fact, we show that in this case the dynamics of the model are very limited: any shock only has an effect on impact, but not in subsequent periods.

In contrast, if the young are taxed, each generation in equilibrium pays as tax the amount that the previous generation earned on its financial assets during its lifetime. In this case, central bank asset purchases change the composition of the youngs' portfolio, and therefore changes its average return, and have the potential to affect their real decisions.

\subsection{Equilibrium}

This section characterizes the equilibrium of the model. Let $x_{j, t} \in\left\{c_{j, t}^{Y}, c_{j, t}^{O}, h_{j, t}, y_{j, t}, m_{j, t}^{Y}, g_{j, t, t+2}^{Y}\right\}$ denote the vector of household $j$ 's choices. A symmetric rational expectations equilibrium is a set of contingent plans $\left\{c_{j, t}^{Y}, c_{j, t}^{O}, h_{j, t}, y_{j, t}, m_{j, t}^{Y}, g_{j, t}^{Y}\right\}$, prices, taxes, a nominal interest rate and bond purchases by the central bank, $\left\{P_{t}^{c}, P_{t, t+1}^{g}, P_{t, t+2}^{g}, \tau_{t}^{Y}, \tau_{t}^{O}, i_{t}, g_{t}^{C B}\right\}$, and exogenous processes $\left\{\omega_{t}, \varepsilon_{i, t}, \varepsilon_{g, t}\right\}$, satisfying at all dates $t$, for all households $j$, and at all states:

$$
\begin{aligned}
\frac{\partial U}{\partial m_{j, t}^{Y}} & =0 \\
\frac{\partial U}{\partial g_{j, t, t+2}^{Y}} & =0 \\
\frac{\partial U}{\partial h_{j, t}} & =0 \\
P_{t}^{c} c_{j, t}^{O} & =m_{j, t}^{Y}+P_{t, t+2}^{g} g_{j, t, t+2}^{Y}+\tau_{t}^{Y} \\
P_{t}^{c} c_{j, t}^{O} & =m_{j, t-1}^{Y}\left(1+i_{t-1}\right)+P_{t, t+1}^{g} g_{j, t-1, t+1}^{Y}-\tau_{t}^{O} \\
y_{j, t} & =\omega_{t} h_{j, t}^{\alpha} \\
1 / P_{t, t+1}^{g} & =1+i_{t} \\
g_{t, t+2}^{Y}+g_{t}^{C B} & =\gamma \\
c_{t}^{Y}+c_{t}^{O} & =y_{t} \\
\tau_{t}^{Y}+\tau_{t}^{O} & =m_{t-1}^{Y} i_{t-1}+\left(P_{t, t+1}^{g}-P_{t-1, t+1}^{g}\right) g_{t-1, t+1}^{Y} \\
i_{t} & =a_{1}+a_{2}\left(\omega_{t}-\mu_{\omega}\right)+\varepsilon_{i, t} \\
g_{t}^{C B} & =\varepsilon_{g, t}
\end{aligned}
$$

In equilibrium, all households of a given cohort make the same decisions. (6) is household $j$ 's first-order condition with respect to the young's money holdings; (7) the first-order condition with respect to bond holdings; and $(8)$ the first-order condition with respect to labor supply. The first-order conditions for money and bonds can be expressed in the typical Euler equation form. Substituting the budget constraints for a young household's consumption into the lifetime 
utility yields

$$
\begin{aligned}
& U \\
= & \frac{1}{1-\sigma_{c}}\left(\left(\left(\omega_{t} h_{j, t}^{\alpha}-\left(\tau_{t}^{Y}+m_{j, t}^{Y}+P_{t, t+2}^{g} g_{j, t, t+2}^{Y}\right) / P_{t}^{c}\right)^{1-\rho}\left(1-h_{j, t}\right)^{\rho}\right)^{1-\sigma_{c}}-1\right) \\
& +\beta E_{t}\left[\frac{1}{1-\sigma_{c}}\left(\left(\left(m_{j, t}^{Y}\left(1+i_{t}\right)+P_{t+1, t+2}^{g} g_{j, t, t+2}^{Y}-\tau_{t}^{O}\right) / P_{t+1}^{c}\right)^{(1-\rho)\left(1-\sigma_{c}\right)}-1\right)\right]
\end{aligned}
$$

The optimal solution has first order conditions

- with respect to money holdings, $m_{j, t}$ :

$$
\frac{\partial U}{\partial m_{j, t}^{Y}}=u_{c}^{\prime}\left(c_{j, t}^{Y}, h_{j, t}\right)\left(-\frac{1}{P_{t}^{c}}\right)+\beta E\left[u_{c}^{\prime}\left(c_{j, t+1}^{O}, 0\right) \frac{1+i_{t}}{P_{t+1}^{c}}\right]=0
$$

where we denote the marginal utility with respect to consumption as

$$
u_{c}^{\prime}(c, h)=(1-\rho) c^{\left(1-\sigma_{c}\right)(1-\rho)-1}(1-h)^{\rho\left(1-\sigma_{c}\right)}
$$

- with respect to holdings of bonds with a remaining maturity of two periods, $g_{j, t, t+2}^{Y}$ :

$$
\frac{\partial U}{\partial g_{j, t}^{Y}}=u_{c}^{\prime}\left(c_{j, t}^{Y}, h_{j, t}\right)\left(-\frac{P_{t, t+2}^{g}}{P_{t}^{c}}\right)+\beta E\left[u_{c}^{\prime}\left(c_{j, t+1}^{O}, 0\right) \frac{P_{t+1, t+2}^{g}}{P_{t+1}^{c}}\right]=0
$$

The first-order conditions for money and bonds can therefore be written as

$$
\begin{aligned}
u_{c}^{\prime}\left(c_{j, t}^{Y}, h_{j, t}\right) & =\beta E\left[\left(1+i_{t}\right) \frac{P_{t}^{c}}{P_{t+1}^{c}} u_{c}^{\prime}\left(c_{j, t+1}^{O}, 0\right)\right] \\
u_{c}^{\prime}\left(c_{j, t}^{Y}, h_{j, t}\right) & =\beta E\left[\frac{P_{t+1, t+2}^{g}}{P_{t, t+2}^{g}} \frac{P_{t}^{c}}{P_{t+1}^{c}} u_{c}^{\prime}\left(c_{j, t+1}^{O}, 0\right)\right]
\end{aligned}
$$

$\left(1+i_{t}\right)\left(P_{t}^{c} / P_{t+1}^{c}\right)$ is the real gross return on money; $\left(P_{t+1, t+2}^{g} / P_{t, t+2}^{g}\right)\left(P_{t}^{c} / P_{t+1}^{c}\right)$ is the real gross return on bonds.

(9) is the budget constraint of the young: the revenues from selling their production (net of own consumption) equals their nominal savings and tax payments. 10 is the budget constraint of the old: they consume their entire savings, net of tax payments. (11) is the production function. 12 says that the gross return of bonds with a remaining maturity of one period must equal that on money: this is because the nominal return of these two assets is known at $t$. (13) and (14) are the market clearing conditions for bonds and the consumption good, respectively. (13) states that per-person purchases of newly issued bonds must equal the net per-person supply of bonds: the difference between issuance, $\gamma$, and the amount of newly issued bonds that the central bank buys (per person), $g_{t}^{C B}$. 14 states that in equilibrium, the period $t$ per-person consumption of the old and the young must equal per-person production in $t, y_{t}$.

15. is the fiscal policy rule: taxes are set equal to the government sector's payments to the household sector: this is a balanced budget constraint. (16) and (17) are the monetary 
policy rules, one for the nominal interest rate and the other for the central bank's purchases of newly issued bonds. Notice that together with (??), the budget constraints (9) and (10) imply a condition for equilibrium in the market for money:

$$
m_{t-1}^{Y}\left(1+i_{t-1}\right)+P_{t, t+1}^{g} g_{j, t-1, t+1}^{Y}-\tau_{t}^{O}=m_{t}^{Y}+P_{t, t+2}^{g} g_{j, t, t+2}^{Y}+\tau_{t}^{Y}
$$

The left-hand side is the nominal wealth of the old, net of taxes, which the old use to pay for the consumption good; the right-hand side shows what the young do with the money earned.

After using the symmetry condition (??), (6) - (17) are 13 equations for 14 unknowns. To close the model, we determine how taxes are distributed between the young and the old. The government may be able to levy different (non-zero) taxes on the young and old. We consider this case but also look at situations where fiscal policy is more constrained. We consider two more constrained scenarios:

1. 'Taxing only the young': If only the young are taxed, (??), (9), and $(15)$ imply that the nominal wealth of the young post taxes is constant and so is state-independent:

$$
\begin{aligned}
w_{t}^{Y} & =m_{t}^{Y}+P_{t, t+2}^{g} g_{j, t, t+2}^{Y}=P_{t}^{c} c_{t}^{O}-\tau_{t}^{Y} \\
& =P_{t}^{c} c_{t}^{O}-\left(m_{t-1}^{Y} i_{t-1}+\left(P_{t, t+1}^{g}-P_{t-1, t+1}^{g}\right) g_{t-1, t+1}^{Y}\right) \\
& =\left(m_{t-1}^{Y}\left(1+i_{t-1}\right)+P_{t, t+1}^{g} g_{t-1, t+1}^{Y}\right)-\left(m_{t-1}^{Y} i_{t-1}+\left(P_{t, t+1}^{g}-P_{t-1, t+1}^{g}\right) g_{t-1, t+1}^{Y}\right) \\
& =m_{t-1}^{Y}+P_{t-1, t+1}^{g} g_{t-1, t+1}^{Y}=w_{t-1}^{Y}
\end{aligned}
$$

We impose the initial condition that $w_{-1}^{Y}=w$.

2. 'Taxing only the old': if only the old are taxed, (??), (10), and (15) imply that the nominal wealth of the old post taxes is equal to their nominal wealth when they were young:

$$
\begin{aligned}
w_{t}^{O} & =m_{t-1}^{Y}\left(1+i_{t-1}\right)+P_{t, t+1}^{g} g_{t-1, t+1}^{Y}-\tau_{t}^{O} \\
& =m_{t-1}^{Y}\left(1+i_{t-1}\right)+P_{t, t+1}^{g} g_{t-1, t+1}^{Y}-\left(m_{t-1}^{Y} i_{t-1}+\left(P_{t, t+1}^{g}-P_{t-1, t+1}^{g}\right) g_{t-1, t+1}^{Y}\right) \\
& =m_{t-1}^{Y}+P_{t-1, t+1}^{g} g_{t-1, t+1}^{Y}=w_{t-1}^{Y}
\end{aligned}
$$

We impose the initial condition that $w_{-1}^{Y}=w_{0}^{O}=w$.

Notice that only post-tax nominal wealth depends on lagged variables in this model: there is no physical capital, and the monetary policy variables are by construction only functions of contemporaneous shocks, which are by assumption serially uncorrelated. So any link between periods can only be created by changes in nominal wealth. $w_{t}^{O}$ depends on both monetary policy (via the interest rate, $i_{t-1}$, and the central bank's purchases of newly issued bonds, $g_{t-1}^{C B}$ ) and fiscal policy (via the tax regime). If the tax regime is such that $w_{t}^{O}$ is a constant, independently of households' portfolio composition, then central bank bond purchases will not have any effect on equilibrium prices and actions in this model. This is the case when only the old are taxed, but not when the next generation (the young) is taxed: we prove this in Proposition 3 below. 


\section{Results}

We first characterize the first best allocation, and show that it can be implemented if fiscal policy is only constrained to achieve a balanced budget. As it turns out, the implementation of the first best does not rely on the existence of bonds. Central bank purchases of bonds have no role here. We then turn to the impact of central bank asset purchases when the first best cannot be implemented because fiscal policy is constrained further, and investigate optimal monetary policy when either only the young or only the old are taxed.

\subsection{First best allocation and implementation when fiscal policy is only con- strained to achieve a balanced budget}

We define welfare as the unconditional expected utility of all households alive at some point in time:

$$
W=E_{s_{t}}\left[u\left(c_{t}^{Y}, h_{t}\right)+u\left(c_{t}^{O}, 0\right)\right]
$$

where the expectation is over all realizations of the state variables $s_{t}$. To determine the first-best allocation with respect to this definition of welfare, we assume that the social planner chooses labour supply and consumption levels directly. He solves

$$
\max _{\left\{c_{j, t}^{Y}, h_{j, t}, c_{j, t}^{O}\right\}} W
$$

for all households $j$, subject to the condition that aggregate consumption must not exceed aggregate production: $c_{t}^{Y}+c_{t}^{O} \leq y_{t}$. Proposition 1 shows the intuitive result that in the welfare maximizing allocation, the entire production of the perishable good is consumed in each period, and that the marginal utilities of young and old households are the same.

Proposition 1 The first-best allocation is given by the solution to

$$
\begin{aligned}
u_{c}^{\prime}\left(c_{t}^{Y}, h_{t}\right)-u_{c}^{\prime}\left(y_{t}-c_{t}^{Y}, 0\right) & =0 \\
u_{h}^{\prime}\left(c_{t}^{Y}, h_{t}\right)+y_{h}^{\prime} n\left(\omega_{t}, h_{t}\right) u_{c}^{\prime}\left(y\left(\omega_{t}, h_{t}\right)-c_{t}^{Y}, 0\right) & =0
\end{aligned}
$$

for all $t$.

Proof. The first best allocation has the property that all young households at a given point in time produce and consume the same, and all old households at a given point in time consume the same, because the utility function is strictly concave in both consumption and leisure. We therefore restrict attention to allocations that have the following symmetry properties: for all households $i, j$,

$$
\begin{aligned}
c_{i, t}^{Y} & =c_{j, t}^{Y} \\
h_{i, t} & =h_{j, t} \\
c_{i, t}^{O} & =c_{j, t}^{O}
\end{aligned}
$$


We omit individual-specific subscripts in the following. Conditions (26)-(28), together with strictly positive marginal utility of consumption, imply that $c_{t}^{O}=y_{t}-c_{t}^{Y}$ in the first-best allocation. We can therefore write the welfare maximization problem as

$$
\max _{\left\{c_{t}^{Y}, h_{t}\right\}} E\left[u\left(c_{t}^{Y}, h_{t}\right)+u\left(y\left(\omega_{t}, h_{t}\right)-c_{t}^{Y}, 0\right)\right]
$$

The first-order conditions of this problem are, for all $t$, given by (24) and (24).

We solve equations (24) and (24) for the specific utility and productions functions (1) and (11) in the annex; see Proposition 5. Labour supply is constant in the first best allocation, while consumption and production are proportional to the productivity shock.

Proposition 2 shows that the first-best allocation can be implemented under a simple and intuitive combination of tax and interest rate rules. The nominal interest rate is held constant at the inverse of the discount factor. Setting the nominal interest rate at this level encourages a young household to save at the welfare maximizing level. Optimal taxes can be thought of as consisting of two parts. Old households are taxed their entire money holdings after having sold their bonds and then provided with a subsidy worth $c_{t}^{O *} u_{c}^{\prime}\left(c_{t}^{O *}, 0\right)$. This allows them to consume exactly the first-best level $c_{t}^{O *}$ at the prevailing equilibrium price level, independently of their savings decisions when young. The tax rule for young households then ensures that the government's budget is balanced in each period.

Proposition 2 Let $c_{t}^{O *}$ denote the first-best consumption level of old households. The policymaker can implement the first-best allocation by setting

$$
\begin{aligned}
1+i & =1 / \beta \\
\tau_{t}^{O} & =m_{t-1}^{Y}(1+i)+P_{t, t+1}^{g} g_{t-1, t+1}^{Y}-c_{t}^{O *} u_{c}^{\prime}\left(c_{t}^{O *}, 0\right) \\
\tau_{t}^{Y}+\tau_{t}^{O} & =m_{t-1}^{Y} i+\left(P_{t, t+1}^{g}-P_{t-1, t+1}^{g}\right) g_{t-1, t+1}^{Y}
\end{aligned}
$$

Proof. We evaluate the first derivatives of utility with respect to a young household's labour supply, and its holdings of money and bonds, at the first best allocation $\left(c_{t}^{Y *}, h_{t}^{*}, c_{t}^{O *}\right)$ and show that these derivatives are zero under the policy rules (30)-32). Using the production function $y\left(\omega_{t}, h_{t}\right)=\omega_{t} h_{t}^{\alpha}$, the first derivative with respect to labour supply is given by

$$
U_{h}^{\prime}\left(c_{j, t}^{Y}, h_{j, t}\right)=u_{h}\left(c_{j, t}^{Y}, h_{j, t}\right)+\beta E\left[\frac{\partial c_{j, t+1}^{O}}{\partial h_{j, t}} u_{c}^{\prime}\left(c_{j, t+1}^{O}, 0\right) \mid s_{t}\right]
$$

Using the budget constraints $(3)$ and $(4), c_{j, t+1}^{O}$ can be expressed as

$$
\begin{aligned}
c_{j, t+1}^{O} & =\left(m_{j, t}^{Y}\left(1+i_{t}\right)+P_{t+1, t+2}^{g} g_{j, t, t+2}^{Y}-\tau_{t+1}^{O}\right) / P_{t+1}^{c} \\
& =\left(\left(P_{t}^{c}\left(\omega_{t} h_{j, t}^{\alpha}-c_{j, t}^{Y}\right)-P_{t, t+2}^{g} g_{j, t, t+2}^{Y}-\tau_{t}^{Y}\right)\left(1+i_{t}\right)+P_{t+1, t+2}^{g} g_{j, t, t+2}^{Y}-\tau_{t+1}^{O}\right) / P_{t+1}^{c}
\end{aligned}
$$


In equilibrium, $\partial c_{j, t+1}^{O} / \partial h_{j, t}=\omega_{t}\left(1+i_{t}\right) P_{t}^{c} / P_{t+1}^{c}$ and so the derivative of a young household's lifetime utility with respect to labour supply is

$$
U_{h}^{\prime}\left(c_{j, t}^{Y}, h_{j, t}\right)=u_{h}^{\prime}\left(c_{j, t}^{Y}, h_{j, t}\right)+\omega_{t} \beta E\left[\left(1+i_{t}\right) \frac{P_{t}^{c}}{P_{t+1}^{c}} u_{c}\left(c_{j, t+1}^{O}, 0\right) \mid s_{t}\right]
$$

The first derivative of a young household's lifetime utility with respect to money savings is

$$
U_{m}^{\prime}\left(c_{j, t}^{Y}, h_{j, t}\right)=-u_{c}^{\prime}\left(c_{j, t}^{Y}, h_{j, t}\right)+\beta E\left[\left(1+i_{t}\right) \frac{P_{t}^{c}}{P_{t+1}^{c}} u_{c}^{\prime}\left(c_{j, t+1}^{O}, 0\right) \mid s_{t}\right]
$$

and the first derivative with respect to bond savings is

$$
U_{b}^{\prime}\left(c_{j, t}^{Y}, h_{j, t}\right)=-u_{c}^{\prime}\left(c_{j, t}^{Y}, h_{j, t}\right)+\beta E\left[\frac{P_{t+1, t+2}^{g}}{P_{t, t+2}^{g}} \frac{P_{t}^{c}}{P_{t+1}^{c}} u_{c}^{\prime}\left(c_{j, t+1}^{O}, 0\right) \mid s_{t}\right]
$$

Denote the first best allocation by $\left(c_{t}^{Y *}, h_{t}^{*}, c_{t}^{O *}\right)$. The first-order conditions of the first-best allocation problem, 24) and (25), imply that

$$
\begin{aligned}
u_{c}^{\prime}\left(c_{t}^{Y *}, h_{t}^{*}\right) & =u_{c}^{\prime}\left(c_{t}^{O *}, 0\right) \\
-u_{h}^{\prime}\left(c_{t}^{Y *}, h_{t}^{*}\right) & =\omega_{t} u_{c}^{\prime}\left(c_{t}^{O *}, 0\right)
\end{aligned}
$$

Evaluating $(33)-(35)$ at the first-best allocation yields

$$
\begin{aligned}
U_{h}^{\prime}\left(c_{j, t}^{Y}, h_{j, t}\right) & =\omega_{t} u_{c}^{\prime}\left(c_{t}^{O *}, 0\right)-\omega_{t} \beta E\left[\left(1+i_{t}\right) \frac{P_{t}^{c}}{P_{t+1}^{c}} u_{c}^{\prime}\left(c_{t+1}^{O *}, 0\right) \mid s_{t}\right] \\
U_{m}^{\prime}\left(c_{j, t}^{Y}, h_{j, t}\right) & =-u_{c}^{\prime}\left(c_{t}^{O *}, 0\right)+\beta E\left[\left(1+i_{t}\right) \frac{P_{t}^{c}}{P_{t+1}^{c}} u_{c}^{\prime}\left(c_{t+1}^{O *}, 0\right) \mid s_{t}\right] \\
U_{b}^{\prime}\left(c_{j, t}^{Y}, h_{j, t}\right) & =-u_{c}^{\prime}\left(c_{t}^{O *}, 0\right)+\beta E\left[\frac{P_{t+1, t+2}^{g}}{P_{t, t+2}^{g}} \frac{P_{t}^{c}}{P_{t+1}^{c}} u_{c}^{\prime}\left(c_{t+1}^{O *}, 0\right) \mid s_{t}\right]
\end{aligned}
$$

The final step of the proof shows that under the rules $30-32$, these derivatives are all zero, implying that the decentralized optimal allocation coincides with the first best allocation. Notice first that (33) and (34) just differ by the factor $\omega_{t}$ : so if (34) is zero, then (33) is zero as well. With a constant interest rate, (34) and (35) simplify to

$$
\begin{aligned}
U_{m}^{\prime}\left(c_{j, t}^{Y}, h_{j, t}\right) & =-u_{c}^{\prime}\left(c_{t}^{O *}, 0\right)+\beta E\left[(1+i) \frac{P_{t}^{c}}{P_{t+1}^{c}} u_{c}^{\prime}\left(c_{t+1}^{O *}, 0\right) \mid s_{t}\right] \\
U_{b}^{\prime}\left(c_{j, t}^{Y}, h_{j, t}\right) & =-u_{c}^{\prime}\left(c_{t}^{O *}, 0\right)+\beta E\left[\frac{1 /(1+i)}{P_{t, t+2}^{g}} \frac{P_{t}^{c}}{P_{t+1}^{c}} u_{c}^{\prime}\left(c_{t+1}^{O *}, 0\right) \mid s_{t}\right]
\end{aligned}
$$

Thus, if 36 is zero and $P_{t, t+2}^{g}=1 /(1+i)^{2}$, then 37 is zero as well. Intuitively, without uncertainty about interest rates, the term premium is zero, and there is no role for bonds separate from that of money. Market-clearing prices ensure that the old consume their entire post-tax wealth, $c_{t}^{O *}=w_{t}^{O *} / P_{t}^{c}$. Post-tax wealth when old is given by the sum of money and 
bonds bought when young, plus their respective returns, minus taxes (given by (31)):

$$
\begin{aligned}
w_{t}^{O *} & =m_{t-1}^{Y}(1+i)+P_{t, t+1}^{g} g_{t-1}^{Y}-\tau_{t}^{O} \\
& =c_{t}^{O *} u_{c}^{\prime}\left(c_{t}^{O *}, 0\right)
\end{aligned}
$$

Using (38), (36) simplifies to

$$
\begin{aligned}
U_{m}^{\prime}\left(c_{j, t}^{Y}, h_{j, t}\right) & =-u_{c}^{\prime}\left(c_{t}^{O *}, 0\right)+\beta E\left[(1+i) \frac{P_{t}^{c}}{P_{t+1}^{c}} u_{c}^{\prime}\left(c_{t+1}^{O *}, 0\right) \mid s_{t}\right] \\
& =-u_{c}^{\prime}\left(c_{t}^{O *}, 0\right)+\beta(1+i) E\left[\frac{u_{c}^{\prime}\left(c_{t}^{O *}, 0\right)}{u_{c}^{\prime}\left(c_{t+1}^{O *}, 0\right)} u_{c}^{\prime}\left(c_{t+1}^{O *}, 0\right) \mid s_{t}\right] \\
& =-u_{c}^{\prime}\left(c_{t}^{O *}, 0\right)+\beta(1+i) u_{c}^{\prime}\left(c_{t}^{O *}, 0\right)
\end{aligned}
$$

which is zero if $1+i=1 / \beta$.

With a constant interest rate, there is no role for bonds separate from that of money in our decentralized economy. Bond purchases by the central bank are completely neutral. That said, the tax rule that implements the first best in our model would be difficult to implement in practice: it is, effectively, a tax that depends only on the age of the household. In the following section, we consider tax rules that are more restrictive but probably more realistic - where taxes are levied either only on workers (the young) or only on those who have earned income on their saving (the old).

\subsection{Impact of central bank asset purchases when the first best cannot be implemented}

In the following, we retain the assumption that the government attempts to balance its budget and consider the impact of central bank asset purchases under two specific tax rules. In the first, only the old are taxed; in the second, only the young are taxed. The first tax rule is of interest because we can show that even though bonds are not perfect substitutes for money (the term premium is generally non-zero), central bank asset purchases are neutral. Under the opposite tax rule, where only the young are taxed, central bank asset purchases have a non-zero, albeit economically very small, impact on nominal and real variables.

\subsubsection{The irrelevance of central bank asset purchases when the old are taxed}

Proposition 3 states that when the old face a tax equal to the return on their portfolio, central bank asset purchases have no impact on the term premium.2 Because the nominal interest rate is fixed by the policy rule, this implies that the issuance price of government bonds is independent of central bank asset purchases as well under this tax rule.

The intuition is that in equilibrium portfolio composition has no impact on the post-tax nominal wealth of the old. But asset purchases only affect other variables through changes in the portfolio composition. So asset purchases by the central bank have no effect on other variables if fiscal policy offsets the impact on old people's wealth.

\footnotetext{
${ }^{2}$ The authors are grateful to Stephanie Schmitt-Grohe for suggesting an irrelevance proof.
} 
Proposition 3 also characterizes the slope of the yield curve under this taxation scheme. The slope depends on the correlation between the price of the consumption good, $P_{t+1}^{c}$, and the price at which the old sell their bonds to the central bank, $P_{t+1, t+2}^{g}=1 /\left(1+i_{t+1}\right)$. Recall that the return on money earned between $t$ and $t+1$ is $1+i_{t}$, which is determined in $t$ and uncorrelated with $P_{t+1}^{c}$. If the resale price of bonds is uncorrelated with $P_{t+1}^{c}$, then money and bonds have the same risk characteristics, and the term premium is zero. If, in contrast, the resale price of bonds is positively correlated with the price of goods, they provide a hedge against unexpected inflation, and the term premium is negative. The opposite is true if the correlation is negative.

Notice that the fact that the tax paid by the old is equal to the return on their portfolio only means that changes to the composition of households' portfolio have no impact on the term premium; it does not mean that the term premium is zero. This is because the price of bonds, and hence the term premium, is determined by households' marginal valuation of bonds. Individual households treat taxes they will pay as independent of their own decisions when computing their marginal valuation. (Proposition 3 only shows the existence of an equilibrium with these properties; however, our numerical solutions have not found other equilibria.)

Proposition 3 When the old are taxed, there is an equilibrium such that

1. Conditionally on the central bank's policy rate, the term premium is constant. It is strictly increasing in the central bank's policy rate.

2. The term premium is independent of central bank asset purchases, which are completely neutral.

3. The term premium is negative when the correlation between the resale price of bonds and the price of the consumption good is positive, and vice versa, if households are sufficiently risk-averse $\left(\sigma_{c}>1\right)$.

Proof. Denote the expectation over states in $t+1$ conditional on being in $s_{t}$ by $E_{s_{t+1}}\left[. \mid s_{t}\right]$. Recall that we write $x_{t}$ for the vector of equilibrium actions and $P_{t}$ for the vector of equilibrium prices. Then the the difference in expected returns between bonds and money (the term premium, $\left.\pi_{t}\right)$ is

$$
\pi_{t}=\frac{E_{s_{t+1}}\left[\frac{1}{1+i_{t+1}\left(s_{t+1}\right)} \mid s_{t}\right]}{P_{t, t+2}^{g}}-\left(1+i_{t}\right)
$$

We can replace the issuance price of bonds using the first-order conditions for money and bonds, reproduced here:

$$
\begin{aligned}
& u_{c}^{\prime}\left(c_{j, t}^{Y}, h_{j, t}\right)=\beta E_{s_{t+1}}\left[\left(1+i_{t}\right) \frac{P_{t}^{c}}{P_{t+1}^{c}} u_{c}^{\prime}\left(c_{j, t+1}^{O}, 0\right) \mid s_{t}\right] \\
& u_{c}^{\prime}\left(c_{j, t}^{Y}, h_{j, t}\right)=\beta E_{s_{t+1}}\left[\frac{P_{t+1, t+2}^{g}}{P_{t, t+2}^{g}} \frac{P_{t}^{c}}{P_{t+1}^{c}} u_{c}^{\prime}\left(c_{j, t+1}^{O}, 0\right) \mid s_{t}\right]
\end{aligned}
$$

Recall that the derivatives are computed assuming that each agent realizes that the tax he pays when old may depend on $s_{t+1}$ but is independent of his own decisions. Dividing (41) by (40) 
yields

$$
P_{t, t+2}^{g}\left(s_{t}\right)=\frac{E_{s_{t+1}}\left[\frac{1}{1+i_{t+1}\left(s_{t+1}\right)} \frac{1}{P_{t+1}^{c}} u_{c}^{\prime}\left(\frac{w^{O}}{P_{t+1}^{c}}, 0\right) \mid s_{t}\right]}{\left(1+i_{t}\right) E_{s_{t+1}}\left[\frac{1}{P_{t+1}^{c}} u_{c}^{\prime}\left(\frac{w^{O}}{P_{t+1}^{c}}, 0\right) \mid s_{t}\right]}
$$

Inserting $(42)$ into 39 yields

$$
\begin{aligned}
& \frac{E_{s_{t+1}}\left[\frac{1}{1+i_{t+1}} \mid s_{t}\right]}{P_{t, t+2}^{g}}-\left(1+i_{t}\right) \\
= & E_{s_{t+1}}\left[\frac{1}{1+i_{t+1}} \mid s_{t}\right] \frac{\left(1+i_{t}\right) E_{s_{t+1}}\left[\frac{1}{P_{t+1}^{c}} u_{c}^{\prime}\left(\frac{w^{O}}{P_{t+1}^{c}}, 0\right) \mid s_{t}\right]}{E_{s_{t+1}}\left[\frac{1}{1+i_{t+1}} \frac{1}{P_{t+1}^{c}} u_{c}^{\prime}\left(\frac{w^{O}}{P_{t+1}^{c}}, 0\right) \mid s_{t}\right]}-\left(1+i_{t}\right) \\
= & \left(1+i_{t}\right)\left[\frac{E_{s_{t+1}}\left[\frac{1}{1+i_{t+1}} \mid s_{t}\right] E_{s_{t+1}}\left[\frac{1}{P_{t+1}^{c}} u_{c}^{\prime}\left(\frac{w^{O}}{P_{t+1}^{c}}, 0\right) \mid s_{t}\right]}{E_{s_{t+1}}\left[\frac{1}{1+i_{t+1}} \frac{1}{P_{t+1}^{c}} u_{c}^{\prime}\left(\frac{w^{O}}{P_{t+1}^{c}}, 0\right) \mid s_{t}\right]}-1\right]
\end{aligned}
$$

The core of the proof is to show that there is an equilibrium in which the expectations in (43) are independent of $s_{t}$. Denote the equilibrium actions of the young in $t+1$ by $x_{t+1}\left(s_{t}, s_{t+1}\right)$ and equilibrium prices in $t+1$ by $P_{t+1}\left(s_{t}, s_{t+1}\right)$. Now choose any two states $s_{t}^{\prime \prime} \neq s_{t}^{\prime}$. To show existence of the equilibrium, we need to show that actions are optimal given prices, and prices clear markets at the optimal actions, at all states. Formally, if $P_{t+1}\left(s_{t}^{\prime \prime}, s_{t+1}\right)=P_{t+1}\left(s_{t}^{\prime}, s_{t+1}\right)$, then $x_{t+1}\left(s_{t}^{\prime}, s_{t+1}\right)$ are optimal at $\left(s_{t}^{\prime \prime}, s_{t+1}\right)$, and if $x_{t+1}\left(s_{t}^{\prime}, s_{t+1}\right)=x_{t+1}\left(s_{t}^{\prime \prime}, s_{t+1}\right)$, then $P_{t+1}\left(s_{t}^{\prime}, s_{t+1}\right)$ clear markets at $\left(s_{t}^{\prime \prime}, s_{t+1}\right)$. The latter part is trivial. For the former part, notice that if $P_{t+1}\left(s_{t}^{\prime \prime}, s_{t+1}\right)=P_{t+1}\left(s_{t}^{\prime}, s_{t+1}\right)$, then $x_{t+1}\left(s_{t}^{\prime}, s_{t+1}\right)$ is feasible at $\left(s_{t}^{\prime \prime}, s_{t+1}\right)$ because the shocks in period $t+1$ are, by construction, independent of $s_{t}$, and the nominal post-tax wealth of the old in $t+1$ is, by construction of the tax rule, independent of $s_{t}$ in equilibrium. And because the price vectors and post-tax wealth are the same, $x_{t+1}\left(s_{t}^{\prime}, s_{t+1}\right)$ is also optimal at $\left(s_{t}^{\prime \prime}, s_{t+1}\right)$.

So there is an equilibrium in which period $t+1$ equilibrium prices and actions do not depend on $s_{t}$. We can therefore write (43) without conditioning on $s_{t}$ as

$$
\begin{aligned}
\pi_{t} & =\frac{E_{s_{t+1}}\left[\frac{1}{1+i_{t+1}\left(s_{t+1}\right)}\right]}{P_{t, t+2}^{g}}-\left(1+i_{t}\right) \\
& =\left(1+i_{t}\left(s_{t}\right)\right)\left[\frac{E_{s_{t+1}}\left[\frac{1}{1+i_{t+1}\left(s_{t+1}\right)}\right] E_{s_{t+1}}\left[\frac{1}{P_{t+1}^{c}} u_{c}^{\prime}\left(\frac{w^{O}}{P_{t+1}^{c}\left(s_{t+1}\right)}, 0\right)\right]}{E_{s_{t+1}}\left[\frac{1}{1+i_{t+1}\left(s_{t+1}\right)} \frac{1}{P_{t+1}^{c}} u_{c}^{\prime}\left(\frac{w^{O}}{P_{t+1}^{c}\left(s_{t+1}\right)}, 0\right)\right]}-1\right]
\end{aligned}
$$

Because the right-hand side of (44) depends on $s_{t}$ only via $i_{t}$, the same is true for the left-hand side. This proves that the term premium is independent of $s_{t}$ conditionally on $i_{t}$, and that it is strictly increasing in $i_{t}$. In particular, the term premium is independent of the central bank bond purchases.

For the third claim, we first note that if $\frac{\partial}{\partial P_{t+1}^{c}}\left(u_{c}^{\prime}\left(\frac{w^{O}}{P_{t+1}^{c}}, 0\right) / P_{t+1}^{c}\right)>0$, then

$$
\operatorname{cov}\left(\frac{1}{1+i_{t+1}\left(s_{t+1}\right)}, \frac{1}{P_{t+1}^{c}} u_{c}^{\prime}\left(\frac{w^{O}}{P_{t+1}^{c}\left(s_{t+1}\right)}, 0\right)\right)
$$


has the same sign as $\operatorname{cov}\left(\frac{1}{1+i_{t+1}\left(s_{t+1}\right)}, P_{t+1}^{c}\right)$. The denominator of the fraction in 44 can be written as

$$
\begin{aligned}
& E_{s_{t+1}}\left[\frac{1}{1+i_{t+1}} \frac{1}{P_{t+1}^{c}} u_{c}^{\prime}\left(\frac{w^{O}}{P_{t+1}^{c}}, 0\right)\right] \\
= & \operatorname{cov}\left(\frac{1}{1+i_{t+1}}, \frac{1}{P_{t+1}^{c}} u_{c}^{\prime}\left(\frac{w^{O}}{P_{t+1}^{c}}, 0\right)\right)+E_{s_{t+1}}\left[\frac{1}{1+i_{t+1}}\right] E_{s_{t+1}}\left[\frac{1}{P_{t+1}^{c}} u_{c}^{\prime}\left(\frac{w^{O}}{P_{t+1}^{c}}, 0\right)\right]
\end{aligned}
$$

So if $\operatorname{cov}\left(\frac{1}{1+i_{t+1}}, P_{t+1}^{c}\right)>0$, then the fraction in 44 is smaller than one, and the term premium is strictly negative. The opposite is true if $\operatorname{cov}\left(\frac{1}{1+i_{t+1}}, P_{t+1}^{c}\right)<0$. So all that remains to do is to investigate the sign of $\frac{\partial}{\partial P_{t+1}^{c}}\left(u_{c}^{\prime}\left(\frac{w^{O}}{P_{t+1}^{c}}, 0\right) / P_{t+1}^{c}\right)$.

$$
\begin{aligned}
\frac{\partial}{\partial P_{t+1}^{c}}\left(u_{c}^{\prime}\left(\frac{w^{O}}{P_{t+1}^{c}}, 0\right) / P_{t+1}^{c}\right) & =\frac{P_{t+1}^{c} u_{c}^{\prime \prime}\left(\frac{w^{O}}{P_{t+1}^{c}}, 0\right)\left(-\frac{1}{P_{t+1}^{c}}\right)^{2} w^{O}-u_{c}^{\prime}\left(\frac{w^{O}}{P_{t+1}^{c}}, 0\right)}{\left(P_{t+1}^{c}\right)^{2}} \\
& =\frac{-\left(\frac{w^{O}}{P_{t+1}^{c}}\right) u_{c}^{\prime \prime}\left(\frac{w^{O}}{P_{t+1}^{c}}, 0\right) / u_{c}^{\prime}\left(\frac{w^{O}}{P_{t+1}^{c}}, 0\right)-1}{\left(P_{t+1}^{c}\right)^{2} u_{c}^{\prime}\left(\frac{w^{O}}{P_{t+1}^{c}}, 0\right)} \\
& =\frac{\sigma_{c}-1}{\left(P_{t+1}^{c}\right)^{2} u_{c}^{\prime}\left(\frac{w^{O}}{P_{t+1}^{c}}, 0\right)}
\end{aligned}
$$

Thus, as long as households are sufficiently risk-averse $\left(\sigma_{c}>1\right)$, the term premium is strictly negative if the resale price of bonds is positively correlated with the price level, and the term premium is strictly positive if the resale price of bonds is negatively correlated with the price level.

We do not have a corresponding analytical result for the case in which the young are taxed. Instead, we solve the model numerically. In order to proceed with numerical solutions, we first need to set parameters at plausible values. We discuss calibration in the next section.

\subsubsection{Calibration}

There is inevitably a tension between wanting the model to be simple (so using two period lives) and realism. Two period lives means periods must be long. That stretches the nature of the monetary policy decision uncomfortably, because we want the policy rate to be set for one period. But for our purposes what really matters is that we have one asset (a bond) with a life which is significantly longer than the period for which the interest rate set by the central bank can be known with some certainty. Correspondingly, the key characteristic of 'money' in our model is not its maturity but the absence of interest rate risk.

We should think of a period as about half an adult life - so of the order of 25 years. We set the discount factor, $\beta$, to 0.66 , implying a discount rate of 0.5 (or $50 \%$ ). With a 25 year period that corresponds to a discount rate of about $2 \%$ a year.

For the utility function, we set the exponent $\rho$ on consumption and leisure such that in equilibrium hours worked are about a fifth of maximum labor supply, corresponding to the idea that people on average work about 8 hours for 220 days per year, that is $8 \cdot 220 /(24 \cdot 365)=20 \%$ 
of their total time. This is approximately the case for $\rho=2 / 3$. For the CRRA risk aversion parameter, $\sigma_{c}$, we use a value of 2 for our base case but also present results for lower risk aversion.

We assume that the production function is linear in labor. This is a natural assumption in a model that covers the long run but, at the same time, omits capital as an explicit production factor: what we call labor input should best be thought of as a composite capital and labor input. Assuming constant returns to scale then seems plausible.

Nominal post-tax wealth, $w$, and the face value of bonds issued in each period, $\gamma$, are selected such that the central bank's assets (bonds) and liabilities (money) are approximately equal in steady state for a policy rule under which the central bank does not buy newly issued bonds in steady state. In this case, the start-of-period value of the central bank's assets is $(1 /(1+i)) \gamma$, so $m^{Y}=\gamma /(1+i)$. The nominal post-tax wealth of young households is then $w=m^{Y}+\gamma P^{g}$, implying $w / \gamma=1 /(1+i)+P^{g}$. For the optimal monetary policy rule in our base case, the interest rate is around $50 \%$ in steady state, and, approximately $P^{g}=0.45$, so $w / \gamma=1 / 1.5+0.45=1.11$. Normalizing $\gamma=1$ implies $w=1.11$.

We assume that the labor productivity shock has a standard deviation of $20 \%$ and a mean of 1 . This implies that the standard deviation of labor productivity relative to its mean is $S D[y / h] / E[y / h]=S D[\omega h / h] / E[\omega h / h]=20 \%$. This corresponds approximately to the standard deviation of detrended labor productivity in the UK since 1855 over non-overlapping 20-year periods. We assume that the innovations to the central bank's policy rules also have a standard deviation of $20 \%$. For the policy rate, that means, for example, that the central bank deviates from its policy rule by more than $40 p p$ per period (about $1.5 p p$ per year) in $5 \%$ of all cases. For the central bank's purchases of newly issued bonds, it means that the central bank deviates from its policy rule by purchasing more than $40 \%$ of total issuance in only $5 \%$ of all cases.

Table 1 summarizes the parameters of the model.

\subsubsection{The impact of asset purchases when the young are taxed}

Before presenting the impulse responses, we briefly discuss the dynamic properties of the model. Recall that the proof of Proposition 3 also showed that equilibrium in $t+1$ does not depend on $s_{t}$ when the old generation is taxed. Put differently, if the economy is shocked in $t$, it is back in steady state a period later. The situation is different when the young are taxed. Intuitively, this is because the mirror image of 'fiscal consolidation' (adjusting taxes to ensure a balanced budget) in our closed economy is that households' wealth is brought back to its pre-shock level. And because wealth is the only variable via which one period can influence choices in future periods (recall that there is no physical capital in the model and that shocks are serially uncorrelated), the choice of which generation's taxes are adjusted also determines when the economy returns to steady state.

When the young (i.e., the next generation) are taxed, the economy, once hit by a temporary shock in period $t$, returns to steady state two periods later. (We show this formally in Proposition 4 , which is in the annex.) For example, if the central bank increases its purchases of bonds in period $t$ only, the composition of young households' portfolio in $t$ changes. Let us suppose 
that their nominal wealth in $t+1$ increases in response. This would tend to increase the price of the consumption good in $t+1$, and may affect real variables in both $t$ and $t+1$. But the post-tax amount of money that the young can invest in $t+1$ remains constant; and the change in nominal wealth of the old has no impact on the central bank's policy rate in $t+1$, nor on the issuance price of bonds in $t+1$ (intuitively, this is because the price of bonds depends on future, not past distributions of household consumption). So young households will make exactly the same investment decisions in $t+1$ as in steady state. The value of their portfolio when old in $t+2$ will be as in steady state, bringing the economy back to steady state in $t+2$.

Tables 2-4 show the (stochastic) steady state and the impulse response function for shocks to central bank asset purchases, productivity, and bank rate, for the interest rate rule that maximizes welfare among linear rules (16). We use a central bank rule for the policy rate that is linear in productivity and which maximizes welfare across all such linear rules; this monetary policy rule is subject to the zero lower bound and it will not attain the first best. For the base case this rule means that the central bank sets its interest rate to $50.5 \%$ per period when all shocks are at their mean, and increases the policy rate if productivity is above average. It does so in a way such that when the productivity shock is $20 \%$ above average ( 1 standard deviation) the policy rate is 33pp higher. This rule is symmetric for below average productivity. We define the stochastic steady state as a situation in which all current shocks are at their mean, but households are uncertain about future realizations of the shocks.

Tables $2 \mathrm{~A}$ and $2 \mathrm{~B}$ show the effect of a shock to central bank asset purchases, the relevant ones for considering the impact of QE. In Table $2 \mathrm{~A}$, the other shocks are at their steady state levels. In Table $2 \mathrm{~B}$, the asset purchase shock occurs when the nominal interest rate is zero.

To facilitate the comparison, column 1 of Table $2 \mathrm{~A}$ shows the stochastic steady state. Columns 2 and 3 show the outcomes in periods $t$ and $t+1$ when asset purchases are 1.5 standard deviations above the mean in period $t$ only which means that the central bank buys $30 \%$ of new bonds issued; columns 4 and 5 show changes relative to steady state. In steady state, and following the particular rule for the policy rate, and with no central bank asset purchases, inflation is expected to be almost zero ( $7.3 \%$ over a period that we can think of as about 25 years). This means that the expected real return on money is close to the nominal policy rate. Notice however that the expected equilibrium return on bonds is higher than that on money ( $51 \%$ on bonds against $50.5 \%$ on money). This failure of the pure expectations theory reflects a combination of two factors. High productivity means that the policy rate rises, so the price at which the central bank purchases bonds with a remaining maturity of one period falls in high productivity states of the world. High productivity also means high production, so the price of the consumption good is low. Correspondingly, the price at which the central bank purchases bonds rises when the price level is high. So bonds provide some insurance against productivity shocks. This tends to lower the term premium. But the interest rate, and hence the price at which the central bank purchases bonds, is also subject to monetary policy shocks which are independent of productivity shocks. This makes bonds riskier than money and tends to raise the term premium. On balance, the term premium is marginally positive.

The central bank purchases $30 \%$ of newly issued bonds as a result of the shock; households purchase the remaining $70 \%$. The size of the shock is comparable to the share of bonds that 
the Fed and the Bank of England have bought since 2009. Comparing column 1 and column 2 of table $2 \mathrm{~A}$ shows that this substantial purchase, if made at the stochastic steady state where the nominal interest rate is far from the zero lower bound, has almost no impact on nominal or real variables in our model. The price of newly issued bonds rises somewhat from $46 \%$ to $46.4 \%$ of their nominal value. The expected nominal portfolio return falls. But because the young expect to have lower wealth when old, they also expect the price level to be lower. On balance, they expect the real return on their portfolio to rise, and respond by (very marginally) reducing consumption and increasing labor supply and production. But all these effects are very small.

Table $2 \mathrm{~B}$ shows that the effects of central bank asset purchases are somewhat stronger when they occur at the zero lower bound for the nominal interest rate. But they remain economically very small. Columns 1 and 2 of table $2 \mathrm{~B}$ show the impact of asset purchases when productivity falls to 2 standard deviations below its mean in the same period in which the central bank purchases bonds. (Under the optimal linear policy rule, the decline in productivity would reduce the policy rate to $-14 \%$ in the absence of a zero lower bound.) Columns 3 and 4 of Table $2 \mathrm{~B}$ show the corresponding impact when an innovation to the central bank policy rate reduces the nominal interest rate to zero. In both cases, the issuance price of bonds rises by slightly more than table $2 \mathrm{~A}$ (compare column 4 of table $2 \mathrm{~A}$ with columns 1 and 2 of table $2 \mathrm{~B}$ ) when the central bank purchases bonds. The response of production is almost the same, but the response of consumption is marginally greater when asset purchases occur at the zero lower bound.

Table 3 shows the results for the case in which the central bank's interest rate rule is shocked. The central bank's policy rate increases from $50.5 \%$ to $70.5 \%$ as a result of the policy shock. Aggregate wealth of the old falls in response (bonds with a remaining maturity of one period are now worth less), but is expected to increase in $t+1$. Expected inflation to the next period rises, from $7 \%$ to $15 \%$. The increase is small enough to allow the increase in the nominal interest rate to translate into a (smaller) increase in the real interest rate for both money and bonds. Despite the increase in the real interest rate, young households' savings ratio declines as they somewhat increase consumption and reduce their labor supply. This is the result of the positive wealth effect of the increase in the real interest rate. The reduced labor supply in $t$, together with the decline in the nominal wealth of old households in $t$, means that the period- $t$ price level remains almost unchanged. So the surprise increase in the central bank interest rate does somewhat reduce real activity in our model, but not, as traditionally, because it discourages credit (which we do not have in our model) but because it increases the nominal and real wealth of the current generation of young households at the expense of both the previous generation (the current old, whose assets lose in value) and the unborn generation, which is taxed more to keep the government's budget balanced over time. Current young households respond to this positive wealth effect by consuming more and working and producing slightly less.

Table 4 shows the effect of a shock to productivity. Households' labour supply remains almost unchanged, as the effects of higher productivity and increasing wealth almost offset each other. This translates into substantially higher production $(+15 \%)$. The central bank increases its interest rate by 33pp. This reduces the wealth of the old, who sell their bonds at a lower price (1/1.839 rather than 1/1.505). Higher production and lower nominal wealth of the old have partially offsetting effects on the price level, which on balance declines (by 19\%). This 
also means that starting from a position of high productivity, inflation over the next period is expected to be higher (47\%). Higher expected inflation adds to the impact of the lower policy rate. So the expected real returns of both money and bonds both fall when productivity today is high. Nevertheless, the positive income effect of higher productivity means that the savings rate remains virtually unchanged.

Because the policy rate rises in $t$, the issuance price of bonds falls, such that young households earn more on their portfolio. So the old in $t+1$ have more money to buy the goods of the young. As a result, the equilibrium price level in $t+1$ is above its steady state level, old households consume more in real terms, and young households supply slightly more labor as the marginal return from work is higher than in steady state. In line with Proposition 4 , the issuance price of bonds is back at its steady state level.

Table 5 demonstrates that our main result - that central bank asset purchases are almost neutral in this model - holds for a range of values for the key parameters of the model, households' risk aversion and the standard deviation of the productivity shock. In Table 5, columns 2-5 show various alternative settings for parameters which describe the economic environment. Columns 6 and 7 show the parameters of the optimal interest rate rule. Columns 8-11 show the impact response of bond yields, expected inflation, real consumption, and the savings ratio, to a surprise increase in central bank bond purchases $(+1.5$ standard deviations, corresponding to the central bank buying $30 \%$ of newly issued bonds in the base calibration) when the economy is at the steady state. The key feature of Table 5 is that in all cases, the impacts of central bank asset purchases shown in columns 13-16 are small. But asset purchases are not neutral. When we impose complete ineffectiveness we find that the household's first order conditions no longer hold. The size of those errors at the equilibrium that yields very small (but non-zero) impacts of asset purchases is numerically trivial which means our solution technique works well. But if we impose a zero impact of asset purchases the errors are $10^{8}$ times as large ${ }^{3}$

\section{Conclusions}

We have developed a simple and highly stylized model of the economy to assess whether shifts in the balance sheet of the central bank have a significant impact on real variables. Analytical solutions to that model are not, in general, available. So we turn to simulations of a calibrated version of this OLG model. We find that across a fairly wide set of environments - with different rules for the setting of interest rates and different ways in which fiscal policy is conducted - the impact of asset purchases working through a portfolio re-balancing channel is weak or absent. Because our periods are long, one could interpret this result as showing that the central bank swapping shorter-dated bonds for longer-dated bonds is relatively ineffective, at least when financial markets are operating normally.

That result does not show that central bank asset purchases (quantitative easing) do not work. And it certainly does not show that the major expansion of the balance sheets of the

\footnotetext{
${ }^{3}$ For example, in the base case (row 1), the sum of the deviations of the first order conditions $(6)-(8)$ from zero is 8e-14. Evaluated at the impact responses (which require a degree of interpolation between the nodes in the state space of our model), the sum of these deviations is 3.2e-9. Had we shocked bond purchases while holding all other variables at their steady state values, the sum of the deviations would be 1.65.
} 
central banks in the US, UK, Japan and in the euro zone in recent years have been ineffective. We reach a different conclusion, which is that the main way in which such balance sheet changes have worked is probably not through the operation of a portfolio rebalancing of private sector portfolios undertaken in an environment of normally functioning financial markets. But largescale asset purchases undertaken in an environment when financial markets are not working normally may well have significant effects. Indeed, there is substantial empirical evidence that they do. Such effects may reflect limits to arbitrage in stressed conditions. Vayanos and Vila (2009) focus on such limits. And there are alternative channels through which asset purchases may work. Durre and Pill (2012), for example, argue that the main way in which the central bank using its balance sheet has affected the wider economy is through providing alternatives to intermediation flowing through markets that have been disrupted.

We believe that our results are nonetheless relevant to the large-scale asset purchases undertaken by central banks since 2008. Those purchases were made when financial markets were, to varying extents, dysfunctional. The unwinding of such asset purchases is likely to occur when financial markets are operating more normally. The results that we report suggest that if the unwinding of large-scale purchases happens when market conditions are more normal they may have relatively little impact on asset prices and the real economy.

\section{Annex}

\subsection{Computational solution strategy}

We reduce the model to two equations in $\left(c_{t}^{Y}, P_{t+2}^{g}\right)$ by entering the production function 11, the budget constraints (9) and (10), and the market clearing conditions for the consumption good and bonds, (14) and (13), into the first-order conditions for money and bonds, (22) and (23). This yields the equilibrium condition

$$
u_{c}^{\prime}\left(c_{t}^{Y}, h_{t}\right)=\beta E_{t}\left[\frac{m_{t-1}^{Y}\left(1+i_{t-1}\right)+\left(\gamma-g_{t-1}^{C B}\right) /\left(1+i_{t}\right)}{m_{t}^{Y}\left(1+i_{t}\right)+\left(\gamma-g_{t}^{C B}\right) /\left(1+i_{t+1}\right)} \frac{c_{t+1}^{O}}{c_{t}^{O}} u_{c}^{\prime}\left(h_{t+1}^{\alpha}-c_{t+1}^{Y}, 0\right)\right]
$$

We also exploit that in equilibrium, optimal labour supply only depends on contemporaneous consumption of the young: $1-h_{t}=\rho /(1-\rho) c_{t}^{Y}$. This yields

$$
\begin{aligned}
u_{c}^{\prime}\left(c_{t}^{Y}, h_{t}\right) & =(1-\rho)\left(\frac{1-h_{t}}{c_{t}^{Y}}\right)^{\rho} \frac{1}{\left(\left(c_{t}^{Y}\right)^{1-\rho}\left(1-h_{t}\right)^{\rho}\right)^{\sigma}} \\
& =(1-\rho)\left(\frac{\rho}{1-\rho}\right)^{-\rho(\sigma-1)}\left(c_{t}^{Y}\right)^{-\sigma}
\end{aligned}
$$

and

$$
\begin{aligned}
u_{c}^{\prime}\left(h_{t+1}^{\alpha}-c_{t+1}^{Y}, 0\right) & =(1-\rho)\left(c_{t+1}^{O}\right)^{-(\rho+(1-\rho) \sigma)} \\
& =(1-\rho)\left(\omega_{t+1} h_{t+1}-c_{t+1}^{Y}\right)^{-(1-\rho)(\sigma-1)} \\
& =(1-\rho)\left(\omega_{t+1}\left(1-\frac{\rho}{1-\rho} c_{t+1}^{Y}\right)-c_{t+1}^{Y}\right)^{-(1-\rho)(\sigma-1)}
\end{aligned}
$$


Entering (46) and (47) into the equilibrium condition (45) yields

$$
\begin{aligned}
& \left(\omega_{t}\left(1-\frac{\rho}{1-\rho} c_{t}^{Y}\right)-c_{t}^{Y}\right)\left(\frac{\rho}{1-\rho}\right)^{-\rho(\sigma-1)}\left(c_{t}^{Y}\right)^{-\sigma} \\
= & \beta\left(1+i_{t}\right)\left(m_{t-1}^{Y}\left(1+i_{t-1}\right)+\left(\frac{\gamma-g_{t-1}^{C B}}{1+i_{t}}\right)\right) \\
\cdot & E_{t}\left[\frac{\left(\omega_{t+1}\left(1-\frac{\rho}{1-\rho} c_{t+1}^{Y}\right)-c_{t+1}^{Y}\right)^{-(1-\rho)(\sigma-1)}}{m_{t}^{Y}\left(1+i_{t}\right)+\left(\gamma-g_{t}^{C B}\right) /\left(1+i_{t+1}\right)}\right]
\end{aligned}
$$

which we solve numerically for some initial guess for each node in the grid of state variables. We choose the lagged policy variables and the shocks as state variables. $i_{t}, i_{t+1}$, and $g_{t}^{C B}$ are computed from the contemporaneous shocks using the interest and bond purchase rules (??) and (??). We solve the expectation using Gauss-Hermite integration (we report results for at least 9 nodes in each dimension). This yields a 5D-grid of equilibrium outcomes for $c_{t+1}^{Y}$ for each combination of nodes. We evaluate the expectation in (48) using this grid, and compute revised guesses for $c_{t}^{Y}$ in $(48)$, until the revisions become small. The other endogenous variables can then be computed explicitly.

To calculate welfare, we again use Gauss-Hermite integration over all state variables, exploiting that the policy variables are truncated linear functions of the normally distributed shocks: $i_{t}=\max \left\{0, i_{t}^{*}\right\}$ where $i_{t}^{* \sim} N\left(a_{1}, \sqrt{\left(a_{1}\right)^{2}+\sigma_{\varepsilon i}^{2}}\right)$, and $g_{t}^{C B}=\min \left\{\max \left\{0, g_{t}^{C B *}\right\}, \gamma\right\}$ where $g_{t}^{C B * \sim} N\left(b_{1}, \sqrt{\left(b_{1}\right)^{2}+\sigma_{\varepsilon g}^{2}}\right)$.

\subsection{Proposition 4}

Equilibrium when the young are taxed depends on five state variables: the three shocks to productivity, Bank Rate, and central bank bond purchases; and two lagged endogenous variables $l_{t-1}$ and $g_{t-1}^{Y} \cdot g_{t-1}^{Y}$ is the nominal value of the bonds that the household buys in $t-1 . l_{t-1}$ is the amount of money that a young household held in his portfolio at state $s_{t-1}$, remunerated at the policy rate in $t-1$ :

$$
l_{t-1}=m_{t-1}^{Y}\left(1+i_{t-1}\right)
$$

(This is equal to the amount of money this household has when old in $t$ before selling his bonds to the central bank.) The value of the household's portfolio when old is then $w_{t}^{O}=$ $l_{t-1}+g_{t-1}^{Y} /\left(1+i_{t}\right)$.

Proposition 4 When the young are taxed, the price of newly issued bonds, $P_{t, t+2}^{g}$, and the composition of young households' portfolio, $\left(m_{t}^{Y}, g_{t}^{Y}\right)$, are independent of the lagged endogenous variables, $\left(l_{t-1}, g_{t-1}^{Y}\right)$.

Proof. Consider two different values for the lagged endogenous variables: $\left(l_{t-1}, g_{t-1}^{Y}\right)^{\prime}$ and $\left(l_{t-1}, g_{t-1}^{Y}\right)^{\prime \prime}$, and denote the corresponding values of the endogenous variables by prime and double prime. Assume that the equilibrium exists for both values of the lagged endogenous variables. We need to show that $P_{t, t+2}^{g}\left(l_{t-1}^{\prime}, g_{t-1}^{Y \prime}, \sigma_{t}\right)$ is an equilibrium price not only at 
$\left(l_{t-1}^{\prime}, g_{t-1}^{Y \prime}, \sigma_{t}\right)$, but also at $\left(l_{t-1}^{\prime \prime}, g_{t-1}^{Y \prime \prime}, \sigma_{t}\right)$. For it to be an equilibrium price, we must have, first, that $\left(m_{t}^{Y}, g_{t}^{Y}\right)^{\prime}$ are feasible and optimal at $P_{t, t+2}^{g}\left(l_{t-1}^{\prime \prime}, g_{t-1}^{Y \prime \prime}, \sigma_{t}\right)=P_{t, t+2}^{g}\left(l_{t-1}^{\prime}, g_{t-1}^{Y \prime}, \sigma_{t}\right)$, and, second, $P_{t, t+2}^{g}\left(l_{t-1}^{\prime \prime}, g_{t-1}^{Y \prime \prime}, \sigma_{t}\right)=P_{t, t+2}^{g}\left(l_{t-1}^{\prime}, g_{t-1}^{Y \prime}, \sigma_{t}\right)$ must clear the market for bonds at $\left(m_{t}^{Y}, g_{t}^{Y}\right)^{\prime}$.

1. Pick any $\left(l_{t-1}, g_{t-1}^{Y}\right)^{\prime \prime} \neq\left(l_{t-1}, g_{t-1}^{Y}\right)^{\prime}$. If $P_{t, t+2}^{g}\left(l_{t-1}^{\prime \prime}, g_{t-1}^{Y \prime \prime}, \sigma_{t}\right)=P_{t, t+2}^{g}\left(l_{t-1}^{\prime}, g_{t-1}^{Y \prime}, \sigma_{t}\right)$, then the tax rule ensures that $\left(m_{t}^{Y}, g_{t}^{Y}\right)^{\prime}$ are feasible at $\left(l_{t-1}, g_{t-1}^{Y}\right)^{\prime \prime}$ : taxes simply add or subtract to the young household's wealth to ensure that his post-tax wealth is constant. So the remunerated value of the young household's money holdings, $l_{t}$, is the same for both sets of values of the lagged endogenous variables. Given that all $(t+1)$-dated variables are only functions of $\left(l_{t}, g_{t}^{Y}\right)$ and $\sigma_{t+1}$, this implies that all $t+1$ - dated variables must be the same for both values of the lagged endogenous variables as well. $\left(m_{t}^{Y}, g_{t}^{Y}\right)^{\prime}$ are also optimal at $\left(l_{t-1}, g_{t-1}^{Y}\right)^{\prime \prime}$ if, from the first-order conditions (6) and (7) for $P_{t, t+2}^{g}$,

$$
\begin{aligned}
P_{t, t+2}^{g}\left(l_{t-1}^{\prime \prime}, g_{t-1}^{Y \prime \prime}, \sigma_{t}\right) & =\frac{\beta E_{\sigma_{t+1}}\left[P_{t+1, t+2}^{g} P_{t}^{c} / P_{t+1}^{c} u_{c}^{\prime}\left(c_{j, t+1}^{O}, 0\right) \mid s_{t}\right]}{u_{c}^{\prime}\left(c_{j, t}^{Y}, h_{j, t}\right)} \\
& =\frac{E_{\sigma_{t+1}}\left[1 /\left(\left(1+i_{t+1}\right) P_{t+1}^{c}\right) u_{c}^{\prime}\left(c_{j, t+1}^{O}, 0\right) \mid s_{t}\right]}{\left(1+i_{t}\right) E_{s_{t+1}}\left[1 / P_{t+1}^{c} u_{c}^{\prime}\left(c_{j, t+1}^{O}, 0\right) \mid s_{t}\right]}
\end{aligned}
$$

Because all $t+1$ - dated variables are the same for both values of the lagged endogenous variables, $P_{t, t+2}^{g}\left(l_{t-1}^{\prime \prime}, g_{t-1}^{Y \prime \prime}, \sigma_{t}\right)=P_{t, t+2}^{g}\left(l_{t-1}^{\prime}, g_{t-1}^{Y \prime}, \sigma_{t}\right)$, and $\left(m_{t}^{Y}, g_{t}^{Y}\right)^{\prime}$ are also optimal at $\left(l_{t-1}, g_{t-1}^{Y}\right)^{\prime \prime}$.

2. The bond market clears at $P_{t, t+2}^{g}\left(l_{t-1}^{\prime \prime}, g_{t-1}^{Y \prime \prime}, \sigma_{t}\right)$ because $P_{t, t+2}^{g}\left(l_{t-1}^{\prime}, g_{t-1}^{Y \prime}, \sigma_{t}\right)$ cleared markets, and $\left(g_{t}^{Y}\right)^{\prime}=\left(g_{t}^{Y}\right)^{\prime \prime}$ because the supply of bonds is determined by the central bank's rule, which is independent of the lagged endogenous variables.

\subsection{First best allocation}

Proposition 5 shows that using the CRRA utility function (1) and the production function (11), labour supply is constant in the first best allocation, while consumption of the young and the old are proportional to the productivity shock, $\omega_{t}$.

Proposition $\mathbf{5}$ The first best allocation is given by

$$
\begin{aligned}
h^{*} & :\left(1-h^{*}\right)^{-\sigma}=\left(\frac{\rho}{(1-\rho) \alpha} h^{*}-\left(1-h^{*}\right)\right)^{(1-\rho)(1-\sigma)-1} \\
c_{t}^{Y *} & =\omega_{t} \frac{1-\rho}{\rho}\left(\alpha\left(h^{*}\right)^{\alpha-1}\right)\left(1-h^{*}\right) \\
y_{t}^{*} & =\omega_{t}\left(h^{*}\right)^{\alpha} \\
c_{t}^{O *} & =y_{t}^{*}-c_{t}^{Y *}
\end{aligned}
$$


Proof. Entering the production function (11) and the utility function (1) into the first-order constraint of the planner's problem, (24)-(25), yields $\mathrm{s}^{4}$

$$
\begin{aligned}
& u_{c}^{\prime}\left(c_{t}^{Y}, h_{t}\right)-u_{c}^{\prime}\left(y_{t}-c_{t}^{Y}, 0\right) \\
= & \frac{\partial}{\partial c}\left(\frac{\left(c^{1-\rho}(1-h)^{\rho}\right)^{1-\sigma}-1}{1-\sigma}\right)-\frac{\partial}{\partial c}\left(\frac{\left(\omega h^{\alpha}-c\right)^{(1-\rho)(1-\sigma)}-1}{1-\sigma}\right) \\
= & \frac{(1-\rho)(1-h)^{\rho}}{c^{\rho}\left(c^{1-\rho}(1-h)^{\rho}\right)^{\sigma}}-(1-\rho)\left(h^{\alpha} \omega-c\right)^{\sigma \rho-\rho-\sigma}=0
\end{aligned}
$$

and

$$
\begin{aligned}
& u_{h}^{\prime}\left(c_{t}^{Y}, h_{t}\right)+y_{h}^{\prime}\left(\omega_{t}, h_{t}\right) u_{c}^{\prime}\left(y_{h}^{\prime}\left(\omega_{t}, h_{t}\right)-c_{t}^{Y}, 0\right) \\
= & \frac{\partial}{\partial h}\left(\frac{\left(c^{1-\rho}(1-h)^{\rho}\right)^{1-\sigma}-1}{1-\sigma}\right)+\frac{\partial}{\partial h}\left(\frac{\left(\omega h^{\alpha}-c\right)^{(1-\rho)(1-\sigma)}-1}{1-\sigma}\right) \\
= & -\frac{\rho(c /(1-h))^{1-\rho}}{\left(c^{1-\rho}(1-h)^{\rho}\right)^{\sigma}}+h^{\alpha-1} \alpha \omega(1-\rho)\left(h^{\alpha} \omega-c\right)^{\sigma \rho-\rho-\sigma}
\end{aligned}
$$

Replacing $(1-\rho)\left(h^{\alpha} \omega-c\right)^{\sigma \rho-\rho-\sigma}$ in 54 by the first term in 53 yields

$$
\begin{aligned}
& u_{h}^{\prime}\left(c_{t}^{Y}, h_{t}\right)+y_{h}^{\prime}\left(\omega_{t}, h_{t}\right) u_{c}^{\prime}\left(y_{h}^{\prime}\left(\omega_{t}, h_{t}\right)-c_{t}^{Y}, 0\right) \\
= & -\frac{\rho(c /(1-h))^{1-\rho}}{\left(c^{1-\rho}(1-h)^{\rho}\right)^{\sigma}}+h^{\alpha-1} \alpha \omega \frac{(1-\rho)(1-h)^{\rho}}{c^{\rho}\left(c^{1-\rho}(1-h)^{\rho}\right)^{\sigma}} \\
= & \frac{(c /(1-h))^{-\rho}}{\left(c^{1-\rho}(1-h)^{\rho}\right)^{\sigma}}\left(-\rho(c /(1-h))+h^{\alpha-1} \alpha \omega(1-\rho)\right)
\end{aligned}
$$

This is equal to zero if 50 holds, implying that

$$
\begin{aligned}
\omega h^{\alpha}-c & =\omega h^{\alpha-1}\left(h-(1-h) \frac{1-\rho}{\rho} \alpha\right) \\
\frac{c}{1-h} & =\omega \frac{1-\rho}{\rho} \alpha h^{\alpha-1} \\
c^{1-\rho}(1-h)^{\rho} & =\left(\frac{1-\rho}{\rho} \alpha h^{\alpha-1} \omega\right)^{1-\rho}(1-h)
\end{aligned}
$$

Using (55)-(57) to substitute $c$ out of (54) yields

$$
\begin{aligned}
& -\frac{\rho\left(\omega \frac{1-\rho}{\rho} \alpha h^{\alpha-1}\right)^{1-\rho}}{\left(\left(\frac{1-\rho}{\rho} \alpha h^{\alpha-1} \omega\right)^{1-\rho}(1-h)\right)^{\sigma}}+h^{\alpha-1} \alpha \omega(1-\rho)\left(\omega h^{\alpha-1}\left(h-(1-h) \frac{1-\rho}{\rho} \alpha\right)\right)^{\sigma \rho-\rho-\sigma} \\
= & -\left(\omega h^{\alpha-1}\right)^{1-\rho-(1-\rho) \sigma} \frac{\rho\left((\alpha) \frac{1-\rho}{\rho}\right)^{1-\rho-(1-\rho) \sigma}}{(1-h)^{\sigma}}+\alpha\left(\omega h^{\alpha-1}\right)^{1+\sigma \rho-\rho-\sigma}(1-\rho)\left(h-(1-h) \frac{1-\rho}{\rho} \alpha\right)^{\sigma \rho-\rho}
\end{aligned}
$$

\footnotetext{
${ }^{4}$ We write $c$ for $c_{t}^{Y}$ and omit time subscripts on other variables in the following equations to make them easier to read.
} 
The exponents on $\omega h^{\alpha-1}$ on each term in (58), $1+\sigma \rho-\rho-\sigma$ on the first and $1-\rho-(1-\rho) \sigma$ on the second, are equal, implying that the optimal labour supply is independent of the productivity shock:

$$
\begin{aligned}
& u_{c}^{\prime}\left(c_{t}^{Y}, h_{t}\right)-u_{c}^{\prime}\left(y_{t}-c_{t}^{Y}, 0\right) \\
= & \left(\omega h^{\alpha-1}\right)^{(1-\rho)(1-\sigma)} \frac{1-\rho}{\alpha}\left(\alpha \frac{1-\rho}{\rho}\right)^{(1-\rho)(1-\sigma)-1} \\
& \cdot\left(-\frac{1}{(1-h)^{\sigma}}+\left(\frac{\rho}{(1-\rho) \alpha} h-(1-h)\right)^{(1-\rho)(1-\sigma)-1}\right)
\end{aligned}
$$

Setting (59) to zero yields 49 .

\section{References}

Chamley, C and H Polemarchakis (1984): "Assets, general equilibrium, and the neutrality of money", Review of Economic Studies 51, pages 129-138.

Durre, A. and Pill, H (2012): "Central Bank Balance Sheets as Policy Tools", Bank for International Settlement papers no 66.

Eggertson, G. and Woodford, M. (2003): "The Zero Bound on Interest Rate and Optimal Monetary Policy", Brookings Papers on Economic Activity 34(1), pages 139-211.

Gagnon, J; Raskin, M; Remache, J; and Sack, B. (2010): "Large Scale Asset Purchases by the Federal Reserve: Did they Work?", FRB New York Staff Report no 441.

Joyce, M; Lasaosa, A.; Stevens, I and Tong, M. (2010): "The Financial Market Impact of Quantitative Easing", Bank of England Working paper no. 393.

Joyce, M; Miles, D; Scott, A; and Vayanos, D (2012): "Quantitative Easing and Unconventional Monetary Policy", The Economic Journal 122 (November), pages 271-289.

Sargent, T J and B D Smith (1987): "Irrelevance of open market operations in some economies with government currency being dominated in rate of return", American Economic Review 77(1), pages 78-92.

Sims, C (2013), "Paper Money", American Economic Review 103(2), pages 563-84.

Vayanos, D and J-L Vila (2009): "A preferred-habitat model of the term structure of interest rates", NBER Working Paper No 15487.

Wallace, N (1981), "A Modigliani-Miller theorem for open-market operations", American Economic Review 71(3), pages 267-274.

Weill, P (2008), "Overlapping Generations: The First Jubilee", Journal of Economic Perspectives 22(4), pages 115-134.

Zampolli, F (2012), "Sovereign Debt Management as an Instrument of Monetary Policy: An Overview", Bank for International Settlements Paper 65. 
Table 1: Calibration

$\begin{array}{llc}\text { Parameters } & & \text { calibration } \\ \beta & \text { Discount factor } & 2 / 3 \\ \rho & \text { Exponent of leisure in utility function } & 2 / 3 \\ \sigma_{c} & \text { CRRA coefficient } & 2 \\ \alpha & \text { Exponent of labour in production function } & 1 \\ \gamma & \text { Amount of bonds issued in each period } & 1 \\ w^{y} & \text { Nominal wealth of young HHs net of taxes when only young } & 1.11 \\ & \text { households are taxed } & \\ \text { Shocks } & & \\ \mu_{\omega} & \text { mean productivity shock } & 1 \\ \sigma_{\omega} & \text { SD of productivity shock } & 0.2 \\ \sigma_{\varepsilon, i} & \text { SD of CB interest rate innovation } & 0.2 \\ \sigma_{\varepsilon, g} & \text { SD of CB bond purchase innovation } & 0.2\end{array}$


Table 2A: Shock to central bank bond purchases at the steady state

\begin{tabular}{l|c|cc|cc|} 
& SS & $\begin{array}{c}\text { on } \\
\text { impact }\end{array}$ & $\begin{array}{c}\text { one period } \\
\text { later }\end{array}$ & $\begin{array}{c}\text { Changes relative to SS } \\
\text { on } \\
\text { impact }\end{array}$ & $\begin{array}{c}\text { one period } \\
\text { later }\end{array}$ \\
\hline & $\mathbf{1 1}$ & $\mathbf{( 2 )}$ & $\mathbf{( 3 )}$ & $\mathbf{( 4 )}$ & $\mathbf{( 5 )}$ \\
\hline Productivity & 1 & 1 & 1 & 0 & 0 \\
CB innovation on policy rate & 0 & 0 & 0 & 0 & 0 \\
CB innovation on bond purchases & 0 & $30 \%$ & 0 & $30 \mathrm{pp}$ & 0 \\
CB policy rate & $50.5 \%$ & $50.5 \%$ & $50.5 \%$ & 0 & 0 \\
\hline CB bond purchases & 0 & $30 \%$ & 0 & $30 \mathrm{pp}$ & 0 \\
\hline Production & 0.78 & 0.78 & 0.78 & $0.01 \%$ & $0.02 \%$ \\
\hline Consumption of the young & 0.45 & 0.45 & 0.45 & $-0.02 \%$ & $-0.06 \%$ \\
\hline Savings ratio & $43 \%$ & $43 \%$ & $43 \%$ & $0.02 \mathrm{pp}$ & $0.04 \mathrm{pp}$ \\
\hline Wealth of old households & 1.67 & 1.67 & 1.67 & $-0.3 \%$ & 0 \\
\hline Issuance price of bonds & $46.0 \%$ & $46.4 \%$ & $46.0 \%$ & $0.4 \mathrm{pp}$ & 0 \\
\hline Price of consumption good & 4.96 & 4.96 & 4.96 & $-0.05 \%$ & $0.11 \%$ \\
\hline Expected nominal return on bonds & $51.0 \%$ & $49.6 \%$ & $51 \%$ & $-1.4 \mathrm{pp}$ & 0 \\
\hline Expected nominal portfolio return & $50.7 \%$ & $50.2 \%$ & $50.7 \%$ & $-0.5 \mathrm{pp}$ & 0 \\
\hline Expected inflation & $7.3 \%$ & $6.9 \%$ & $7.1 \%$ & $-0.3 \mathrm{pp}$ & $-0.1 \mathrm{pp}$ \\
\hline
\end{tabular}

Table 2B: Shock to central bank bond purchases at the ZLB

\begin{tabular}{|c|c|c|c|c|}
\hline & \multicolumn{2}{|c|}{$\begin{array}{c}\text { Effect of QE when } \\
\text { productivity is 2SDs below } \\
\text { its mean }\end{array}$} & \multicolumn{2}{|c|}{$\begin{array}{l}\text { Effect of QE when the } \\
\text { nominal interest rate is } \\
\text { shocked to ZLB }\end{array}$} \\
\hline & on impact & one period later & on impact & one period later \\
\hline & (1) & (2) & (3) & (4) \\
\hline Productivity & 0 & 0 & 0 & 0 \\
\hline CB innovation on policy rate & 0 & 0 & 0 & 0 \\
\hline $\mathrm{CB}$ innovation on bond purchases & 30pp & 0 & 30pp & 0 \\
\hline CB policy rate & 0 & 0 & 0 & 0 \\
\hline $\mathrm{CB}$ bond purchases & 30pp & 0 & $30 p p$ & 0 \\
\hline Production & $0.01 \%$ & $-0.01 \%$ & $0.01 \%$ & $-0.01 \%$ \\
\hline Consumption of the young & $-0.05 \%$ & $0.04 \%$ & $-0.06 \%$ & $0.04 \%$ \\
\hline Savings ratio & $0.04 p p$ & $-0.03 p p$ & $0.04 p p$ & $-0.03 p p$ \\
\hline Expected wealth of old households & $-1.1 \%$ & $0.0 \%$ & $-1.1 \%$ & $0.0 \%$ \\
\hline Issuance price of bonds & 1.0pp & 0 & 1.0pp & 0 \\
\hline Price of consumption good & $-0.1 \%$ & $-0.1 \%$ & $-0.1 \%$ & $-0.1 \%$ \\
\hline Expected nominal return on bonds & $-1.4 p p$ & 0 & $-1.4 p p$ & 0 \\
\hline Expected nominal portfolio return & $-1.0 p p$ & 0 & $-1.0 p p$ & 0 \\
\hline Expected inflation & $-0.3 p p$ & $0.1 p p$ & $-0.5 p p$ & $0.1 p p$ \\
\hline
\end{tabular}

\footnotetext{
${ }^{1}$ That is, in the period in which the shock occurs.
} 
Table 3: Shock to central bank policy rate

\begin{tabular}{l|c|cc|cc|} 
& SS & $\begin{array}{c}\text { on } \\
\text { impact }\end{array}$ & $\begin{array}{c}\text { one period } \\
\text { later }\end{array}$ & $\begin{array}{c}\text { Changes relative to SS } \\
\text { on } \\
\text { impact }\end{array}$ & $\begin{array}{c}\text { one period } \\
\text { later }\end{array}$ \\
\hline & $\mathbf{1 1}$ & $\mathbf{( 2 )}$ & $\mathbf{( 3 )}$ & $\mathbf{( 4 )}$ & $\mathbf{( 5 )}$ \\
\hline Productivity & 1 & 1 & 1 & 0 & 0 \\
CB innovation on policy rate & 0 & 0.2 & 0 & 0 & 0 \\
CB innovation on bond purchases & 0 & 0 & 0 & 0 & 0 \\
CB policy rate & $50.5 \%$ & $70.5 \%$ & $50 \%$ & $20 \mathrm{pp}$ & $0 \mathrm{pp}$ \\
\hline CB bond purchases & 0 & 0 & 0 & 0 & 0 \\
\hline Production & 0.78 & 0.77 & 0.78 & $-0.6 \%$ & $0.9 \%$ \\
\hline Consumption of the young & 0.45 & 0.46 & 0.43 & $2.2 \%$ & $-3.1 \%$ \\
\hline Savings ratio & $43 \%$ & $41 \%$ & $45 \%$ & $-1.6 \mathrm{pp}$ & $2.3 \mathrm{pp}$ \\
\hline Expected wealth of old households & 1.67 & 1.89 & 1.67 & $13.1 \%$ & 0 \\
\hline Issuance price of bonds & $46 \%$ & $41 \%$ & $46 \%$ & $-5.2 \mathrm{pp}$ & 0 \\
\hline Price of consumption good & 4.96 & 4.94 & 5.29 & $-0.3 \%$ & $6.6 \%$ \\
\hline Expected nominal return on bonds & $51 \%$ & $70 \%$ & $51 \%$ & $19.4 \mathrm{pp}$ & 0 \\
\hline Expected nominal portfolio return & $51 \%$ & $70 \%$ & $51 \%$ & $19.8 \mathrm{pp}$ & 0 \\
\hline Expected inflation & $7 \%$ & $15 \%$ & $1 \%$ & $7 \mathrm{pp}$ & $-7 \mathrm{pp}$ \\
\hline
\end{tabular}

Table 4: Shock to productivity

\begin{tabular}{|c|c|c|c|c|c|}
\hline & \multicolumn{5}{|c|}{ Changes relative to SS } \\
\hline & SS & $\begin{array}{c}\text { on } \\
\text { impact }\end{array}$ & $\begin{array}{c}\text { one period } \\
\text { later }\end{array}$ & $\begin{array}{c}\text { on } \\
\text { impact }\end{array}$ & $\begin{array}{c}\text { one period } \\
\text { later }\end{array}$ \\
\hline & (1) & (2) & (3) & (4) & (5) \\
\hline Productivity & 1 & 1.2 & 1 & $20 \%$ & 0 \\
\hline CB innovation on policy rate & 0 & 0 & 0 & 0 & 0 \\
\hline CB innovation on bond purchases & 0 & 0 & 0 & 0 & 0 \\
\hline CB policy rate & $50.5 \%$ & $83.9 \%$ & $50.5 \%$ & 33pp & Opp \\
\hline CB bond purchases & 0 & 0 & 0 & 0 & 0 \\
\hline Production & 0.8 & 0.9 & 0.8 & $15 \%$ & $1 \%$ \\
\hline Consumption of the young & 0.4 & 0.5 & 0.4 & $15 \%$ & $-5 \%$ \\
\hline Savings ratio & $43 \%$ & $43 \%$ & $46 \%$ & $0.0 p p$ & 3.7pp \\
\hline $\begin{array}{l}\text { Expected wealth of old } \\
\text { households }\end{array}$ & 1.7 & 2.0 & 1.7 & $22 \%$ & 0 \\
\hline Issuance price of bonds & $46 \%$ & $38 \%$ & $46 \%$ & $-8 p p$ & 0 \\
\hline Price of consumption good & 5.0 & 4.0 & 5.5 & $-19 \%$ & $11 \%$ \\
\hline $\begin{array}{l}\text { Expected nominal return on } \\
\text { bonds }\end{array}$ & $51 \%$ & $83 \%$ & $51 \%$ & $32 p p$ & 0 \\
\hline Expected nominal portfolio return & $51 \%$ & $84 \%$ & $51 \%$ & 33pp & 0 \\
\hline Expected inflation & $7 \%$ & $47 \%$ & $-3 \%$ & $40 p p$ & $-11 p p$ \\
\hline
\end{tabular}


Table 5: Impact of alternative parameterisations on steady state

\begin{tabular}{|c|c|c|c|c|c|c|c|c|c|c|}
\hline \multirow[b]{2}{*}{$\begin{array}{c}\# \\
(1) \\
\end{array}$} & \multicolumn{4}{|c|}{ Parameters } & \multicolumn{2}{|c|}{ Optimal interest rate rule } & \multicolumn{4}{|c|}{$\begin{array}{l}\text { Responses to central bank bond purchases ( } 30 \% \text { of new } \\
\text { issuance) at SS when the shock occurs }\end{array}$} \\
\hline & $\begin{array}{c}\text { SD of } \\
\text { productivity } \\
\text { shock } \\
\text { (2) } \\
\end{array}$ & $\begin{array}{c}\text { SD of } \\
\text { innovations to } \\
\text { CB interest rates } \\
\text { policy rule } \\
\text { (3) } \\
\end{array}$ & $\begin{array}{l}\text { SD of innovations } \\
\text { to CB bond } \\
\text { purchase policy } \\
\text { rule } \\
\text { (4) } \\
\end{array}$ & $\begin{array}{l}\text { CRRA } \\
\text { coeffici } \\
\text { ent } \\
\mathbf{( 5 )} \\
\end{array}$ & $\begin{array}{c}\text { Optimal steady } \\
\text { state interest } \\
\text { rate } \\
(\mathbf{6}) \\
\end{array}$ & $\begin{array}{c}\text { Optimal sensitivity } \\
\text { of policy rate to } \\
\text { productivity shock } \\
\text { (7) }\end{array}$ & $\begin{array}{c}\text { Expected } \\
\text { return on } \\
\text { bonds (pp) } \\
\mathbf{( 8 )} \\
\end{array}$ & $\begin{array}{l}\text { Expected } \\
\text { inflation } \\
\text { (pp) } \\
(9) \\
\end{array}$ & $\begin{array}{c}\text { Consumption } \\
\text { of the young } \\
(\%) \\
(10) \\
\end{array}$ & $\begin{array}{c}\text { Savings ratio } \\
\text { (pp) } \\
(\mathbf{1 1}) \\
\end{array}$ \\
\hline 1 & 0.2 & 0.2 & 0.2 & 2.0 & $50 \%$ & 1.67 & -1.37 & -0.35 & $-0.011 \%$ & 0.000 \\
\hline 2 & 0.2 & 0.2 & 0.2 & 1.5 & $51 \%$ & 0.05 & -0.39 & -0.05 & $-0.002 \%$ & 0.000 \\
\hline 3 & 0.2 & 0.2 & 0.2 & 1.25 & $50 \%$ & -0.61 & -0.49 & 0.02 & $-0.002 \%$ & 0.000 \\
\hline 4 & 0.2 & 0.2 & 0.2 & 1.0 & $50 \%$ & -1.55 & -0.96 & 0.06 & $0.000 \%$ & 0.000 \\
\hline 5 & 0.1 & 0.2 & 0.2 & 2.0 & $52 \%$ & 1.35 & -0.58 & -0.10 & $-0.005 \%$ & 0.000 \\
\hline 6 & 0.05 & 0.2 & 0.2 & 2.0 & $52 \%$ & 1.20 & -0.47 & -0.06 & $-0.004 \%$ & 0.000 \\
\hline
\end{tabular}

